\title{
Średniowieczne cmentarzysko kamienne w Siemienicach koło Kutna
}

The Medieval Stone Cemetery in Siemienice near Kutno

Abstrakt: W Muzeum Archeologicznym w Krakowie pod nrami inwentarzowymi MAK/3478, 3664, 4255 przechowywane jest wyposażenie z grobów w Siemienicach koło Kutna: miniaturowy topór z brązu (typ II wg N.A. Makarova, import z Rusi, związany z kultem św. Olafa), dwa żelazne groty włóczni (typy IV i v wg A. Nadolskiego), żeleźce topora (typ vcwgA. Nadolskiego), żelazne fragmenty obręczy i kabłąk (elementy wiadra klepkowego) oraz miniaturowe naczynie gliniane (z cylindryczną szyjką). Obiekty z Siemienic zaliczały się do grobów kamiennych (pochówki szkieletowe przykryte brukiem składające się zwykle na kamienne cmentarzyska). Można je datować na schyłkową fazę kultury drużynnej (2. połowa XI - początek XII w.).

Słowa kluczowe: Polska, średniowiecze, kultura drużynna, groby kamienne, uzbrojenie, topór miniaturowy

W Dziale Zbiorów Dawnych Muzeum Archeologicznego w Krakowie (dalej MAK) przechowywanych jest kilka zabytków z Siemienic ${ }^{1}$ na pograniczu Ziemi Łęczyckiej i Mazowsza (ryc. I, por. też ryc. 2). Nader zwięzła charakterystyka obiektów, w których je znaleziono, oraz przyjęta przez autora interpretacja tych niepozornych przedmiotów rzucają nieco nowego światła na dzieje owego regionu w średniowieczu.

W liście (ryc. 4) datowanym 6go lutego 1853r.w Siemienicach Wincenty Krasiński, właściciel majątku, opisał odkrycie części ze wspomnianych zabytków następująco:

Dwa żelezce od dzid czy też od strzał, szczątki strawionego żelaztwa, metalowe niewiadomego użytku narzędzie, iako też nadłamana łzawniczka, znalezione zostały we wśi Siemienicach w powiećie gostyńskim, na polu nie opodal od

1 Siemienice są wsią w gm. Krzyżanów, pow. kutnowski, woj. łódzkie. Według notatek skreślonych prawdopodobnie ręką B. Podczaszyńskiego stanowisko archeologiczne zajmowało wzgórze piasczyste między wsiami Siemienice i Siemieniczki (ryc. 3: I), a mogło nazywać się Żale (ryc. 3: 2). 
rzeki Bzury. Nadmienia śię że mieysce znalezienia tych przedmiotów, zawalone były massą kamieni, któré niejaką wyniosłość tworzyły i zalegały kilkadziesiąt prętów kwadratowych. Celem przysporzenia pola rudowano owe kamienie i przy takowym rudunku, przedmioty wymienione znaleziono. Dodać ieszcze należy, że w tym samém mieyscu, trafiano na inne ieszcze skorupy iak śię zdaie łzawnic, ale dziwnie ceglastey barwy zupełnie [...]wych. W tém ieszcze mieyscu znaleziono dwa pieniążki zlepione razem, iak twiérdzą znawcy z czasów Władysława Jagiełły i czaszkę ludzką kilkakrotnie rozbitą. Nadsyłaiąc powyżey opisane przedmioty, z wyiątkiem pieniążkow z czasu Wł: Jag: skorup i czaszki, podpisany w zamian pragnąłby mieć od znawcy i lubownika starożytnośći, któremu przedmioty te dostaną śię, wiadomość co o nich wnośi, z iakiey by były epoki i do iakiego właśćiwie słuzyły użytku.

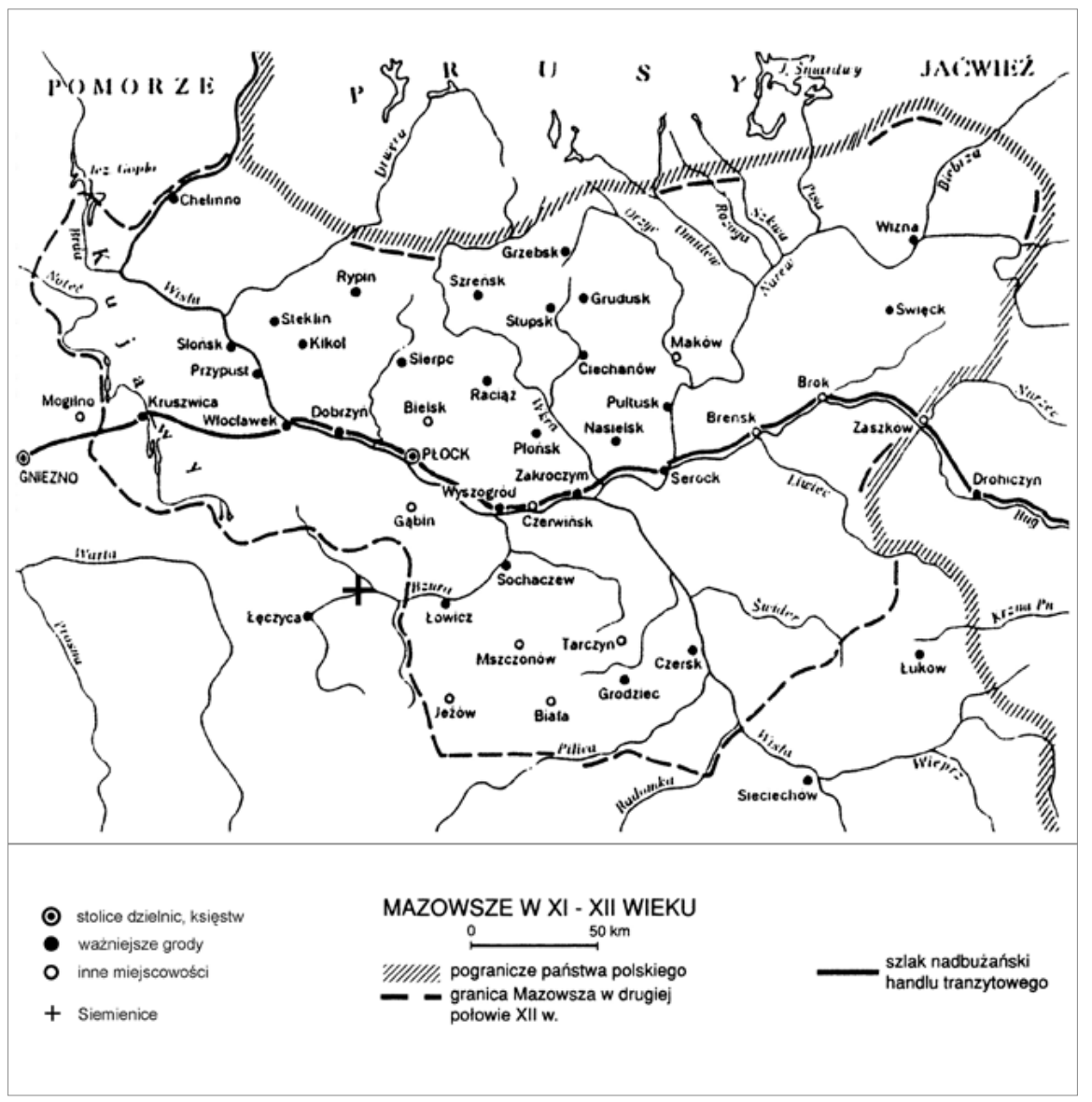

Ryc.1. Mazowsze w XI-XII w. (wg A. Gieysztora za Dulinicz 2000: 223). 


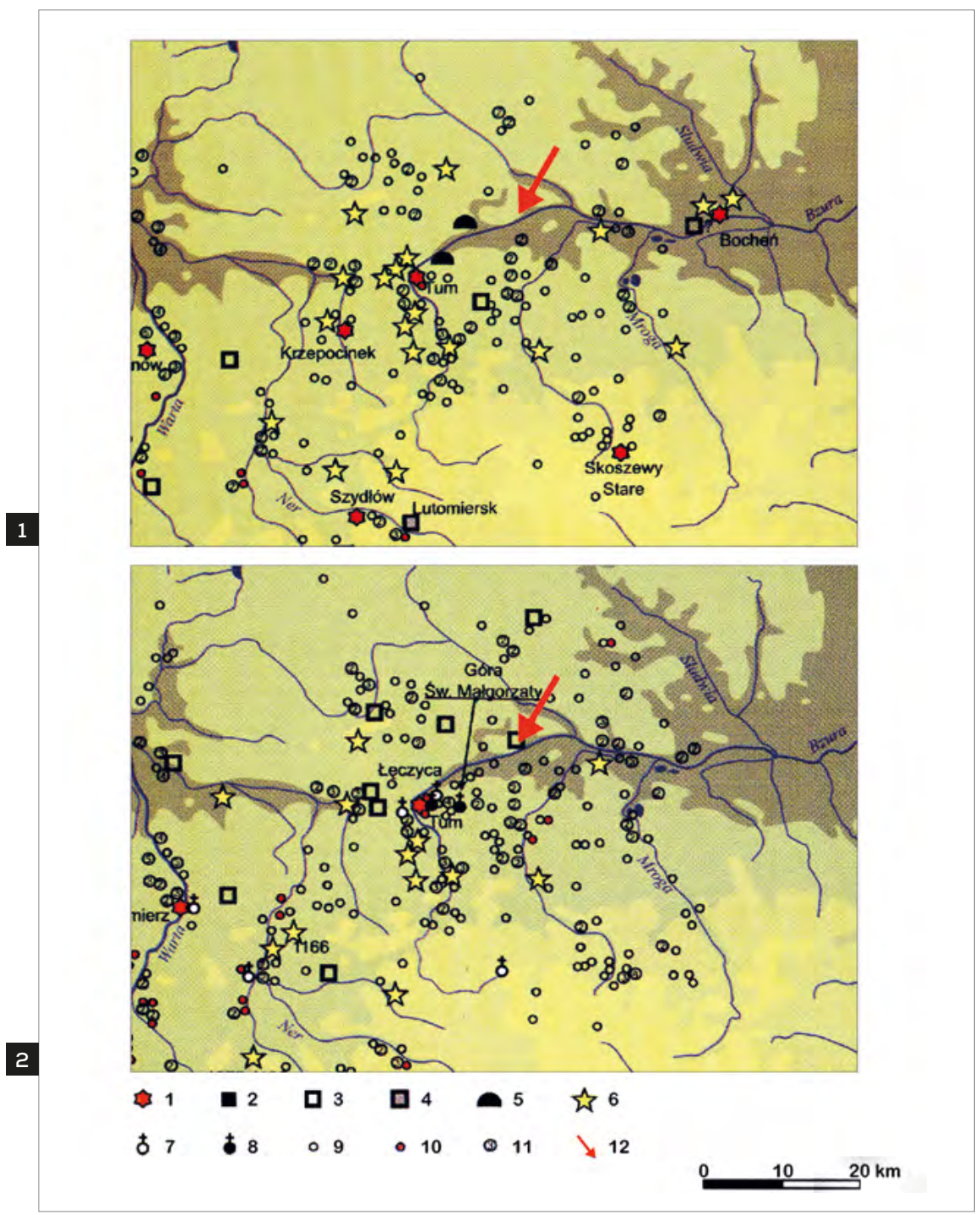

Ryc.2. 1 - osadnictwo w Polsce Centralnej w 2. połowie X - I. połowie XI w.; Ryc.2. 2 - osadnictwo w Polsce Centralnej w 2. połowie XI - I. połowie XIII w.

Legenda: I - grody, 2 - cmentarzyska ciałopalne, 3 - cmentarzyska szkieletowe, 4-cmentarzyska birytualne, 5- cmentarzyska kurhanowe lub wtórne pochówki w kurhanach pradziejowych, 6 - skarby, 7 - kościoły znane ze źródeł pisanych, 8 - kościoły zachowane lub znane z badań archeologicznych, 9 - miejscowości ze stanowiskami rozpoznanymi powierzchniowo, Io - miejscowości ze stanowiskami badanymi wykopaliskowo, II - liczba stanowisk w miejscowości, jeśli jest więcej niż jedno, I2 - lokalizacja Siemienic (wg Sikora 2009: ryc. 4 i 5). 

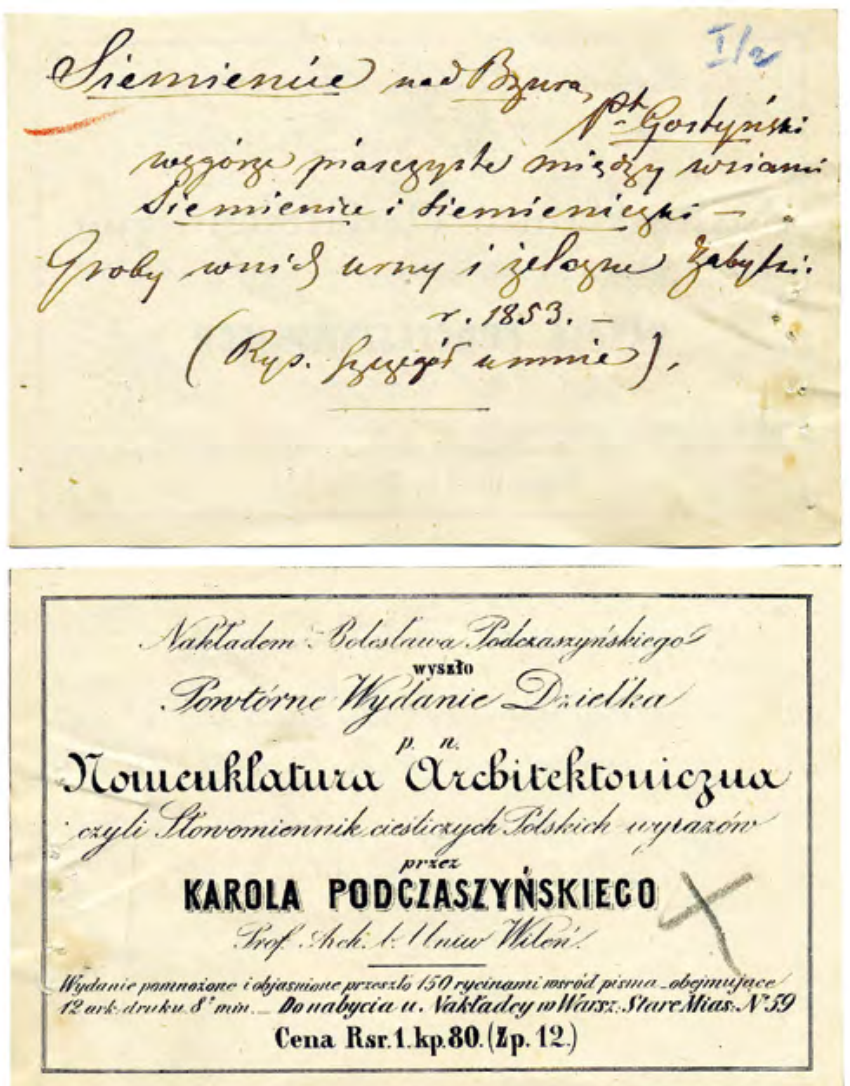

2

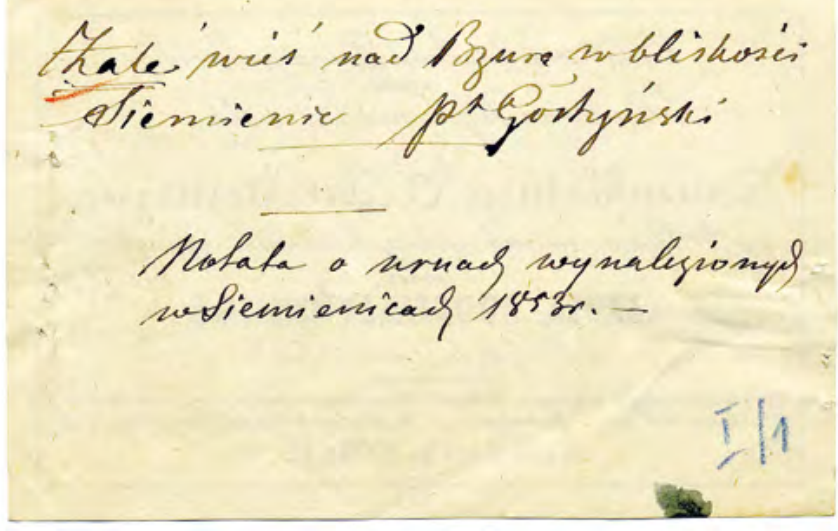

Ryc. 3. Notatki B. Podczaszyńskiego (Archiwum MAK-u). 


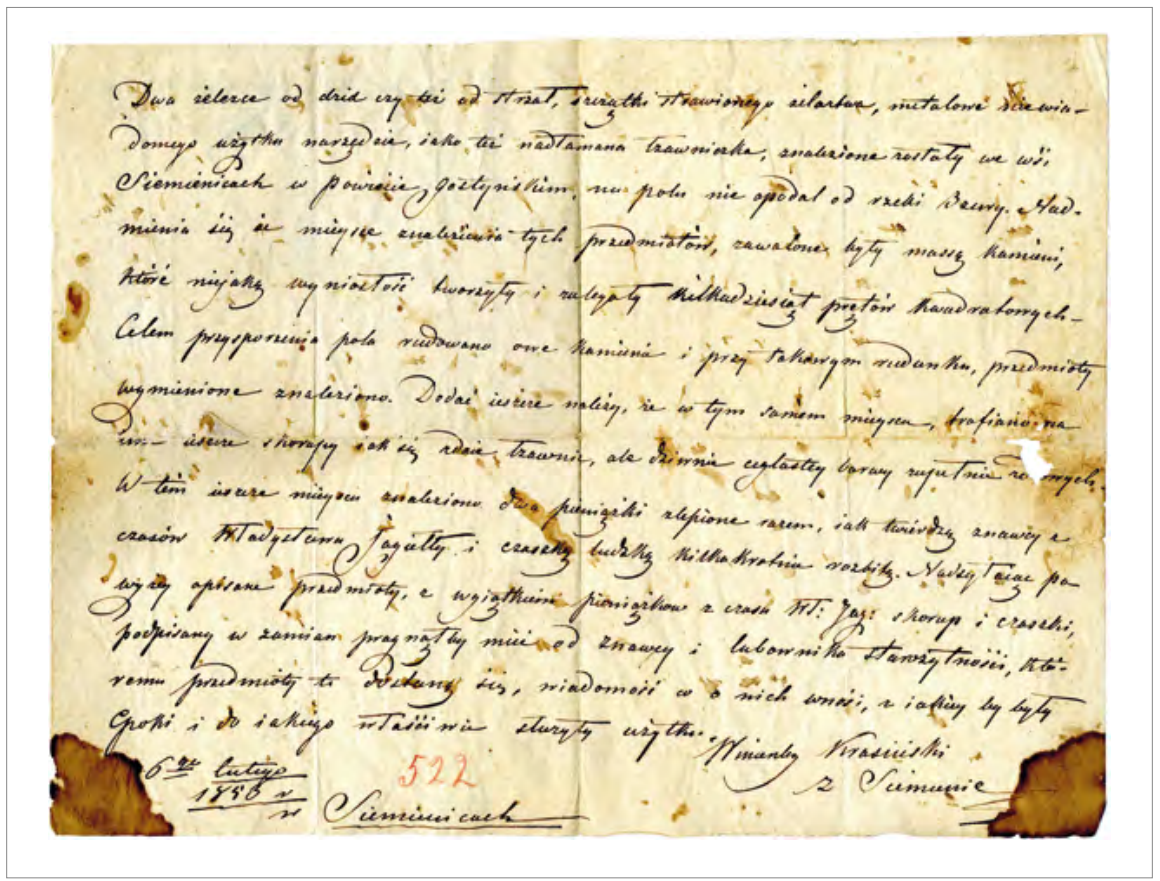

Ryc.4. List W. Krasińskiego (Archiwum MAK-u).

Znalezione w I852 r. zabytki trafiły - wg metryczek (ryc.5-7) już 6 lutego I853 r. - do kolekcji Bolesława Podczaszyńskiego ${ }^{2}$. Od jego spadkobierców w I880 r. zakupiła je Akademia Umiejętności w Krakowie dla będącego wówczas jej częścią Muzeum Archeologicznego (Chochorowska 200I: 13). Obecnie na muzealny zbiór o nrze inw. MAK $/ 3664^{3}$ składają się: miniaturowy topór, grot włóczni, kabłąk i obręcz wiadra oraz bardzo małe naczynie. Niestety, nie ma w kolekcji trzpienia rękojeści miecza lub może gwoździa, żelaznej ostrogi oraz drugiego ostrza od dzidy żelaznego rdzq mocno strawionego (por. metryczki - ryc. 5: 2, 7).

Kolejne zabytki z Siemienic - noszące dziś nry inw. MAK/3478 i MAK/4255 - przekazane zostały do zbiorów MAK-u przez Albina Jurewicza za pośrednictwem Mariana Wawrzenieckiego, który napisał (Wawrzeniecki 1908: 94), że:

2 Dziewiętnastowieczny (1822-1876) polski architekt i kolekcjoner o zainteresowaniach historycznych - archeologią, historią sztuki, dyplomatyką, heraldyką, sfragistyką (szerzej o nim Haisig 1952: 5-31).

3 Informacja jakoby pod nrem inw. MAK/3664 znajdowały się zabytki z epoki brązu (Panasiewicz, Wołoszyn 2002: 259; Kucypera i in. 2011: 21) jest mylna, a w literaturze znalazła się zapewne przez nieporozumienie (w MAK-u przechowywane są materiały kultury łużyckiej z Siemianic w pow. kępińskim, nr inw. MAK/3268). 


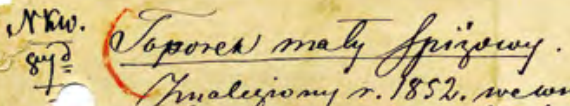

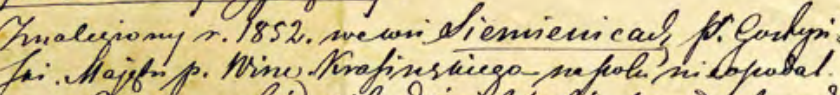

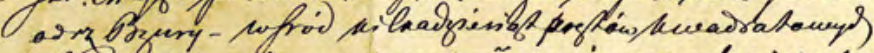

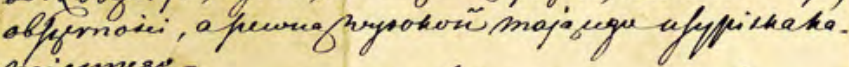

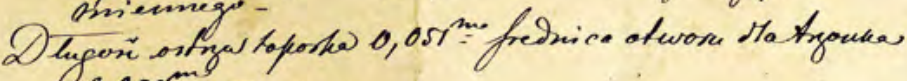
$0,00 g^{m}=$

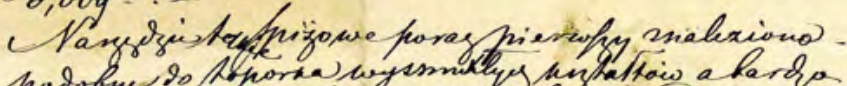

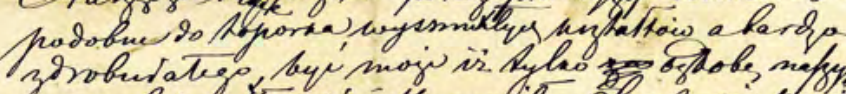

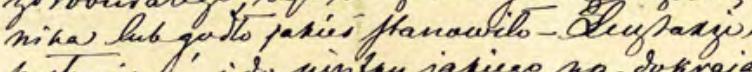

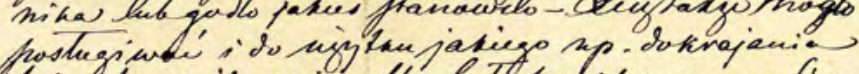

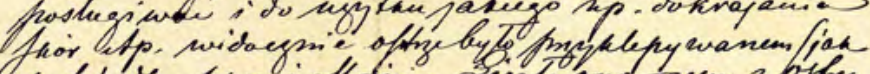

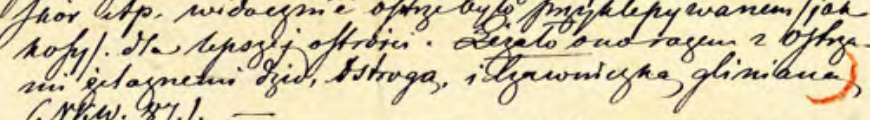
(sthw. $35 \%$

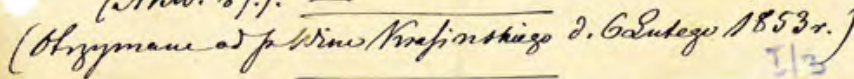

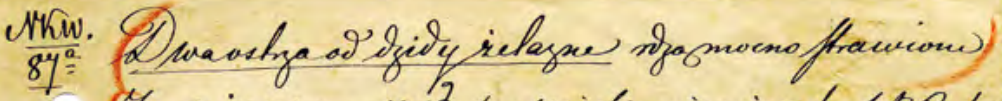

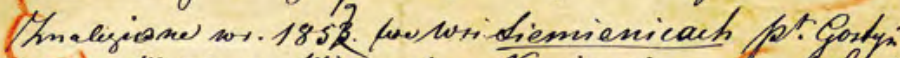

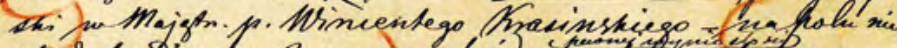

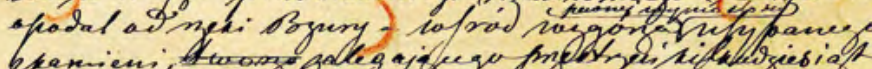
prefoin hevatratoonge of Dlugace oftre sich $1,22,5^{-3}=$ Dagem Lam znalegiono essie jelagney ortroge.

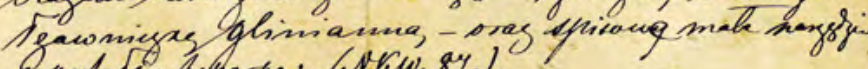

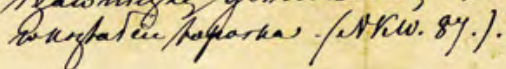

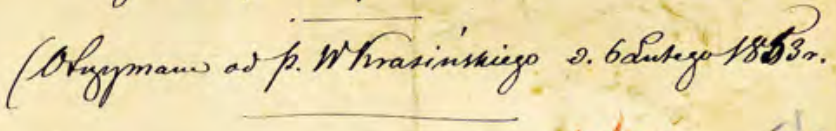

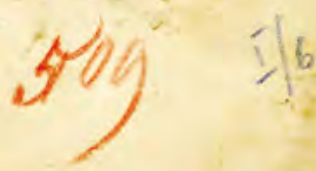

Ryc.5. Pierwotne metryczki siemienickich zabytków z kolekcji B. Podczaszyńskiego (Archiwum MAK-u). 

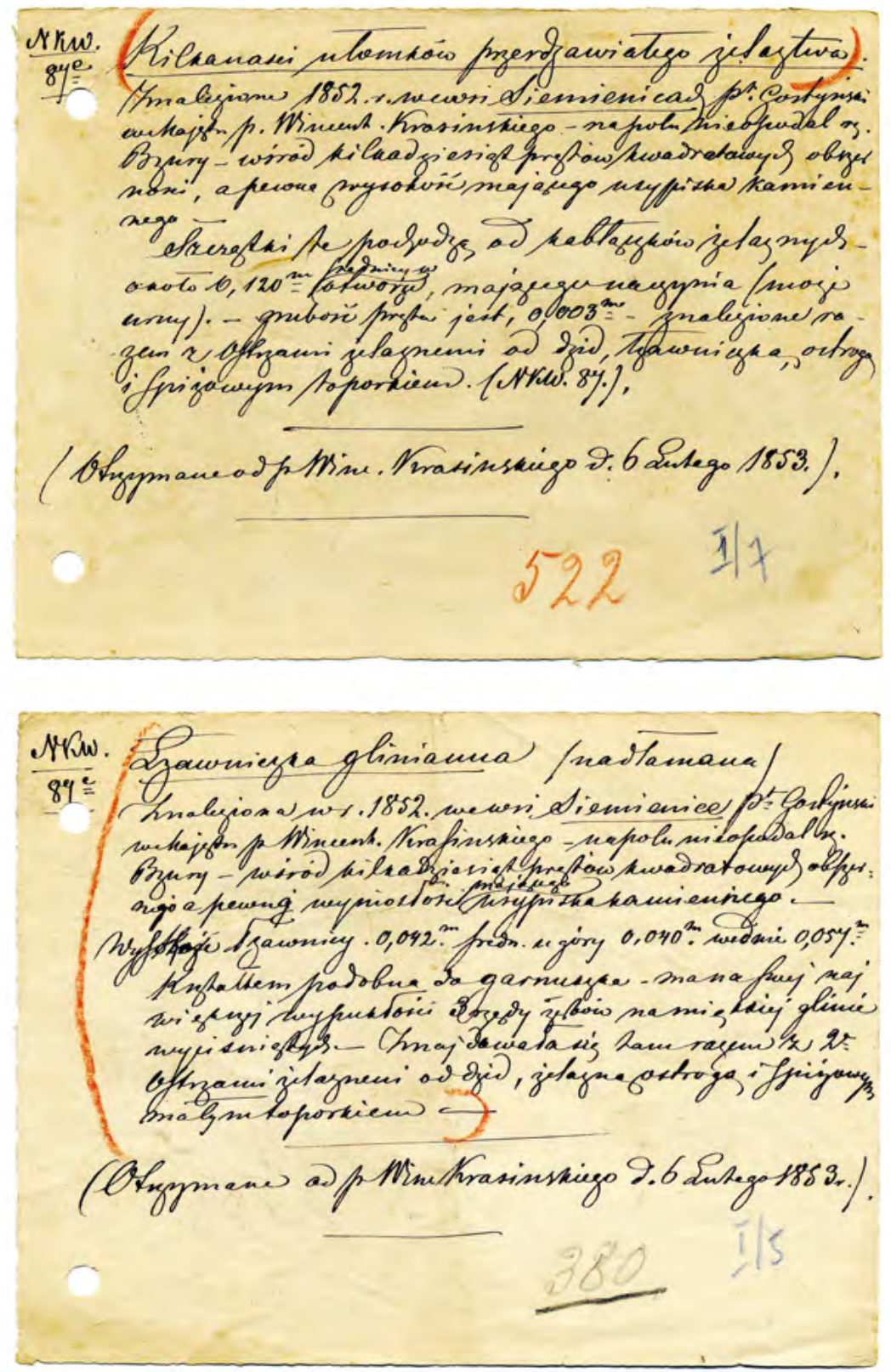

Ryc.6. Pierwotne metryczki siemienickich zabytków z kolekcji

B. Podczaszyńskiego (Archiwum MAK-u). 

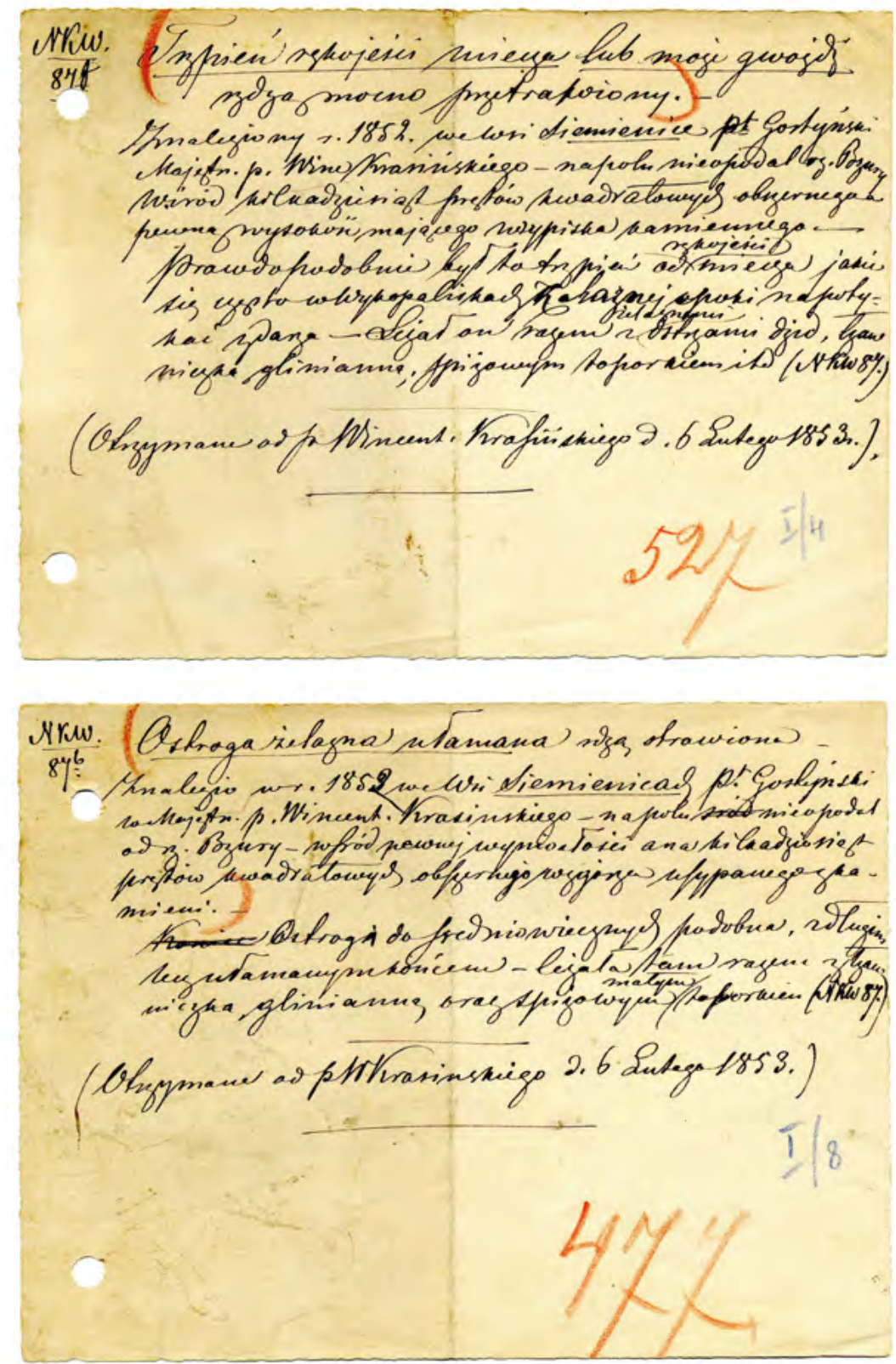

Ryc.7. Pierwotne metryczki siemienickich zabytków z kolekcji B. Podczaszyńskiego (Archiwum MAK-u). 
Dnia I9 listopada 1906 r. zgłosił się p. Albin Jurewicz, budowniczy i ofiarował dla Akad. Um. żelazny grot lancy O.I55 m. długi oraz żelazny toporek O.I m. długi. Oba te przedmioty p. J. zabrał z majątku Siemienice wł. Jw. hr. Tomasza Potockiego, gdzie znaleziono je w następujących okolicznościach. Przy uprawie pola pod buraki (głębsza orka) natrafiono na ułożone kamienie (zwykłe granity) a po ich usunięciu okazały się urny w liczbie 5 , które pokruszono, w urnach były drobne kostki (palone) a przy nich żelazne przedmioty.

Oba krótkie sprawozdania z okoliczności odkryć w Siemienicach pozwalają na przypuszczenie, że znajdowało się tam cmentarzysko (zapewne jedno ${ }^{4}$ ) z grobami kamiennymi5.

Spośród zabytków z Siemienic szczególną uwagę zwraca odlany z brązu miniaturowy topór ${ }^{6}$ (MAK/3664; ryc. 8: I, 9: I), który mógł być zawieszony na szyi lub umocowany przy pasie 7 . Jego część ostrzowa jest wysoka, wachlarzowata, z haczykowatymi występami skierowanymi ku szyjce, nieco niesymetryczna,

4 Lechosław Rauhut (I971: 450-45I) zauważył, że na obszarze o większej koncentracji cmentarzysk kamiennych, stojąc na jednym stanowisku, widzi się trzy lub więcej miejsc pochówku podobnego typu z tego samego okresu.

5 Autor, używając określeń „grób kamienny” i „cmentarzysko kamienne”, ma na myśli groby i zespoły grobów, do których budowy użyto znacznej ilości kamieni. Podobnie nazywane są za wschodnią granicą Polski. W literaturze krajowej zbliżone obiekty określa się jako: „cmentarzyska typu mazowieckiego”, „groby/nekropole z konstrukcjami kamiennymi”, „groby/cmentarzyska w obudowach kamiennych”, ,groby/nekropole kamienne”, "groby w obstawach kamiennych" (por.: Dulinicz 2009: 382-395; Liwoch 2013: 142; Dzik 20I 4: 87), a w starszych publikacjach jako „mogiłę kamienną” (Katalog... I856: I6) i „groby rzędowe kamienne" (Tarczyński 1900). Podstawowym i nadal wartościowym opracowaniem tej kategorii stanowisk polskich jest monografia L. Rauhuta (I97I; niemieckojęzyczny skrót - 1975), która doczekała się wielu uzupełnień oraz różnej wartości korekt lub polemik (m.in.: Skalski 2002; Kordala 2006; Dulinicz 2009; Dzik 2014; 2015; Olczak, Krasnodębski 2019). Michał Dzik zauważył, że nekropole kamienne tworzone były wg dwóch równoległych wzorców, tj. monocentrycznego, gdy zaczątkiem cmentarza był jeden grób, oraz policentrycznego, gdy groby zebrane były w kilka odrębnych skupisk. Przypuszczano, że w poszczególnych grupach (w tym w rzędach) grobów pochowane były osoby z jednego rodu, jednak analizy DNA wykonane dla jedenastu pochówków z Czekanowa w pow. sokołowskim pokazały, że w kolejnych mogiłach spoczywali ludzie niespokrewnieni ze sobą, natomiast potwierdziła się hipoteza o pokrewieństwie osób złożonych w jednej jamie grobowej (Skrzyńska 2019: 286).

6 Bibliografia zabytku: Katalog... 1856: 16-17; Paulsen 1939: 163, 166; 1956: 197; Nadolski 1953: 390; Makarov 1992: 54; Panasiewicz, Wołoszyn 2002: 252, 258-259, 269; Kucypera i in. 2011: 21, 97; Liwoch 2014a: 416-418, 421; 2014b: 324-325, 328, 333.

7 Odnotowano okazy z pozostałościami toporzyska, które raczej nie nadawały się do zawieszania na szyi. Miniatury toporów w grobach znajdowano zwykle przy boku zmarłego na wysokości bioder lub ud (Kucypera i in. 2011: 36-37). 


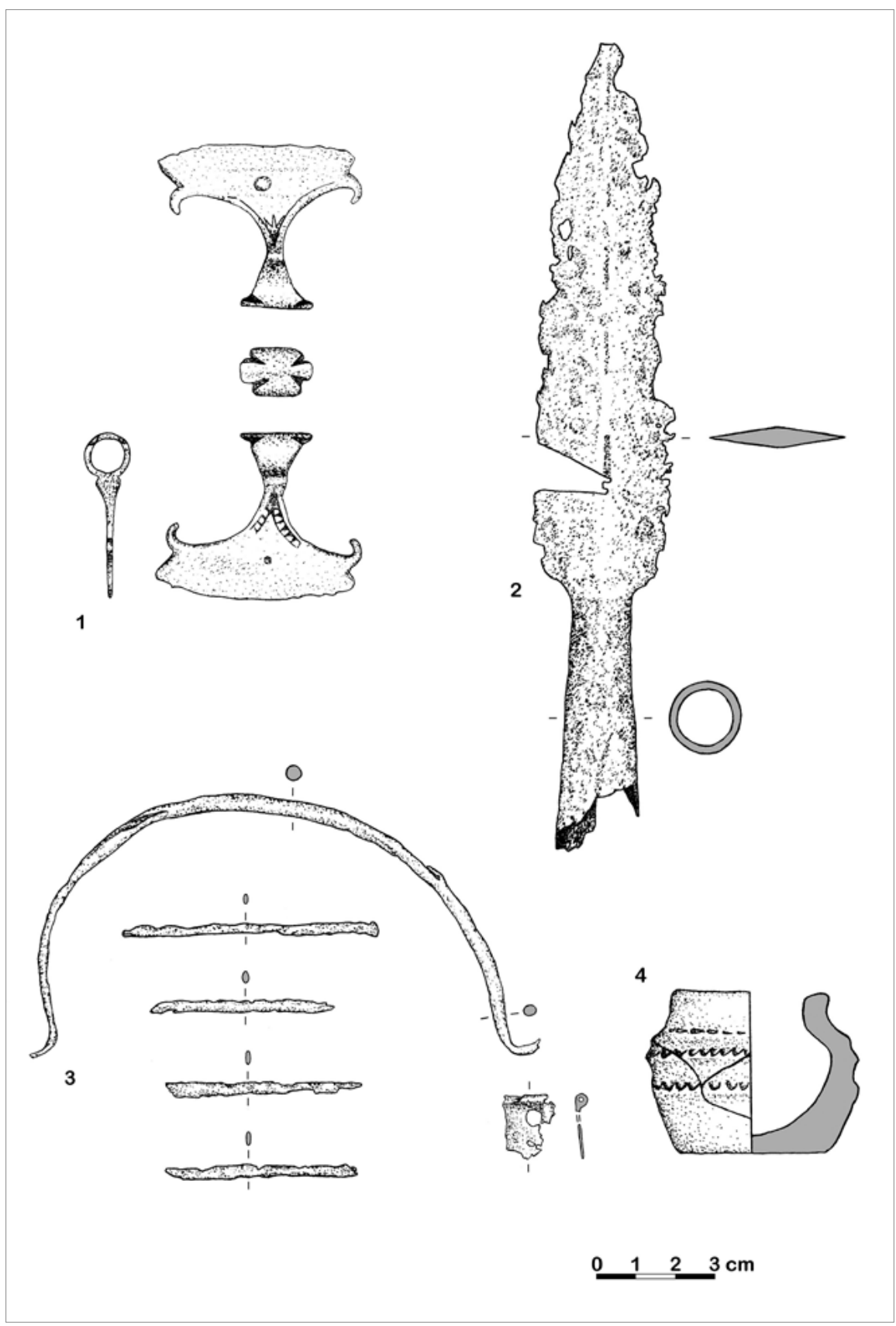

Ryc. 8. Zabytki z grobu (grobów?) kamiennego w Siemienicach (odkrycie z I852 r.): I - miniaturowy topór brązowy; 2 - żelazny grot włóczni; 3 - żelazne fragmenty wiadra; 4- miniaturowe naczynie gliniane (rys. W. Rumian). 


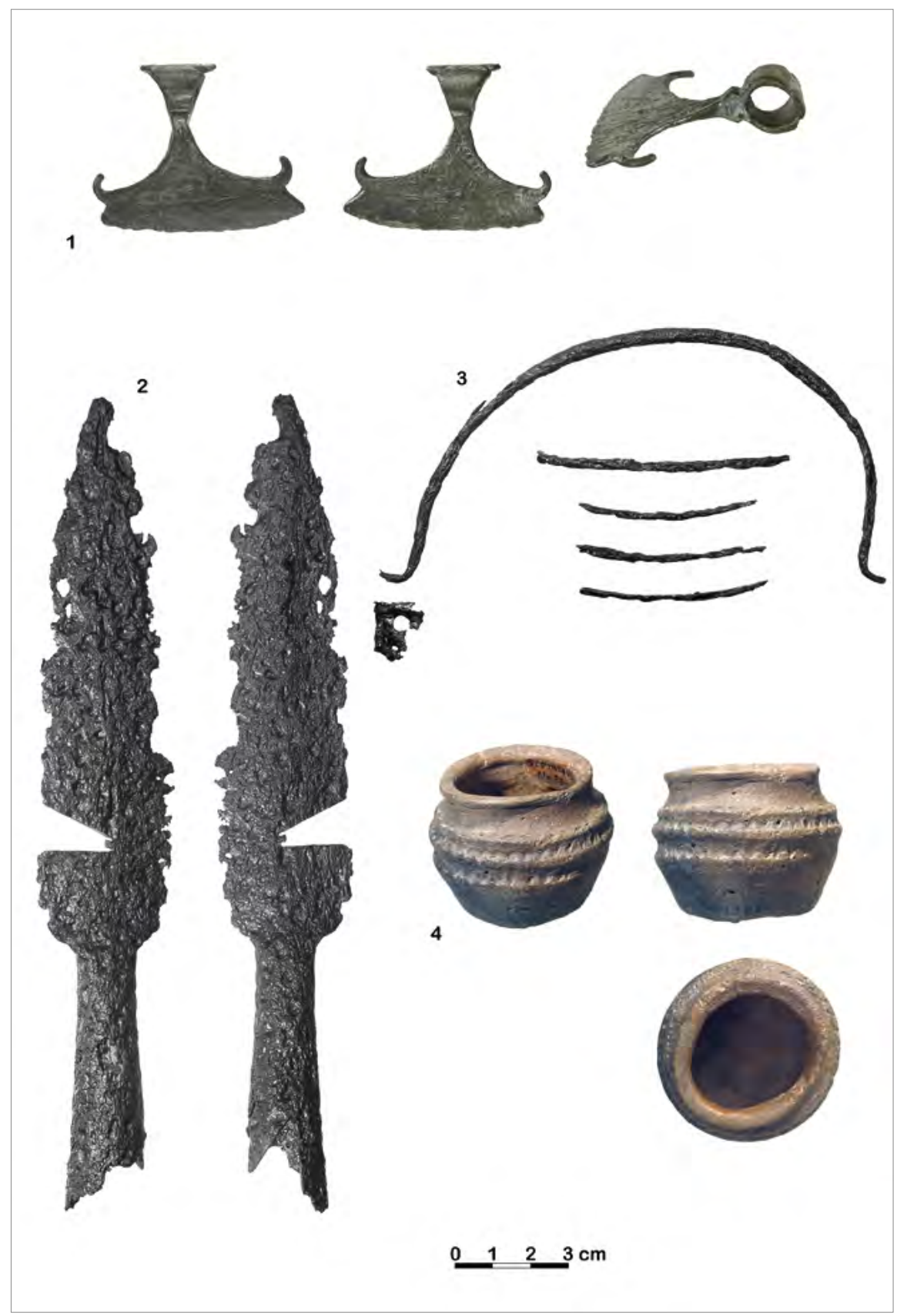

Ryc.9. Zabytki z grobu (grobów?) kamiennego w Siemienicach (odkrycie z I852 r.): I - miniaturowy toporek brązowy; 2 - żelazny grot włóczni; 3 - żelazne fragmenty wiadra; 4-miniaturowe naczynie gliniane (fot. A. Susuł). 
o ostrzu łagodnie łukowatym, obustronnie zdobiona - wzdłuż łukowatych krawędzi bordiura (wzór geometryczny, ledwie widoczny po jednej stronie) oraz centralne koliste wgłębienie (niewyraźne z jednej strony); szyjka przy obuchu uformowana w żeberko, obuch zaś symetryczny, z kapturkiem i słabo zaznaczonymi wąsami. Zachował się w bardzo dobrym stanie (patyna koloru zgniłozielonego z odbarwieniami; z jednej strony zarysowania). Ma wymiary: wysokość całkowita $-5,2 \mathrm{~cm}$, wysokość ostrza $-5,0 \mathrm{~cm}$, długosśc $-4,2 \mathrm{~cm}$, najmniejsza wysokość szyjki - 0,4 cm, szerokość szyi - 0,7 cm, wysokość kapturka- I,9 cm, wysokość wąsów - I, $4 \mathrm{~cm}$, szerokość obucha - I,2 cm, średnica światła osady - 0,8 cm, cię$\dot{z ̇ a r}-$ I2,2 g. Należy do typu II wg klasyfikacji Nikolaja A. Makarova. Podobne przedmioty - nieliczne i nader interesujące wytwory metaloplastyki staroruskiej - były w ostatnich latach przedmiotem wielu publikacji (m.in.: Panasiewicz, Wołoszyn 2002; Kucypera i in. 20II; Fûredi i in. 2018). Ich monografiści podsumowali swe rozważania następująco:

[...] zabytki wymagają raczej ponownego rozpatrzenia możliwości ich interpretacji przy równoczesnym zaznaczeniu, że żadna z dotychczas proponowanych koncepcji nie „posiada” argumentów na tyle twardych, aby uznać je za rozstrzygające w dyskusji nad objaśnianiem funkcji miniaturowych toporków we wczesnym średniowieczu. Wydaje się, że najsłuszniejszym rozwiązaniem będzie zasugerowanie zmiennej atrybucji toporków miniaturowych (Kucypera i in. 2011: 54).

Zdaniem autora nie ma takiej potrzeby, natomiast konieczne jest uściślenie chronologii tych zabytków. Najprawdopodobniej obie ich klasyczne formy - typy I i II wg N.A. Makarova - były swego rodzaju wczesnośredniowiecznym epizodem, niewiarygodne jest bowiem przypuszczenie, by te stosunkowo nieliczne i niemające funkcji utylitarnej przedmioty wytwarzano aż przez ponad dwa stulecia - od końca X do XIII w. Wydaje się, że miniaturowe toporki były w użyciu około połowy i w drugiej połowie XI w., może jeszcze przez część wieku XII ${ }^{8}$. Warto zacytować zdanie wspomnianego badacza (Makarov 1992: 52):

8 Podstawą do takiego przypuszczenia są wydzielone z zestawienia sporządzonego przez Pawła Kucyperę, Piotra Prankego i Sławomira Wadyla (2011: 55-63) stosunkowo dobrze datowane obiekty: dla typu I grób z Dziekanowic (2. połowa XI - I. połowa XII w.), dwa groby z miejscowości Nikol'skoe (3. ćwierć XI w., połowa XI w.) oraz grób z Sarkela-Białej Wieży (XI w.), dla typu II zaś dwa kolejne groby z Nikol'skiego (połowa XI w., 2. połowa XI w.) i grób z Kolčina (2. połowa XI - początek XII w.). Wiele miniaturowych toporów obu typów pochodzi z XI-wiecznych warstw kulturowych na osadach (Sigtuna, Hjelmsølille, Nowogród, Suzdal). 
Po-vidimomu, minâtûrnye toporiki prinadležat $\mathrm{k}$ tomu krugu veŝej - bytovyh predmetov, ukrašenij i kul'tovyh simvolov, kotorye poâvilis' kak innovacii na volne moŝnogo obnovleniâ material'noj kul'tury vostočnyh slavân v XI v.

Tak określona chronologia pozwala odrzucić rozpowszechnioną przez Vladislava P. Darkeviča (196I) interpretację miniaturowych toporów jako symboli gromowładnego Peruna. Zauważyć trzeba, że pomysł, iż epigoni pogańskich wierzeń ostentacyjnie - tworząc niefunkcjonujące wcześniej w życiu codziennym symbole dawnych bogów - manifestowali swój światopogląd religijny w chrześcijańskim państwie, jest niedorzeczny. Inaczej może być tylko na nieschrystianizowanych w XI w. ziemiach bałtyjskich, które jednak podlegały wpływom z Rusi i ze Skandynawii. Dokładniejsza chronologia uwiarygodnia objaśnianie miniaturowych toporów z brązu jako dewocjonaliów - chrześcijańskich amuletów związanych z kultem norweskiego konunga św. Olafa ${ }^{9}$, mającym topór za jeden z atrybutów, który to kult rozwinął się po elewacji relikwii w I03 I r. i ich depozycji w Trondheim (Nidaros). W uzasadnieniu odwołać się można do opinii znawców symboliki hagiograficznej:

Toporowi lub siekierze używanym przez Olafa przypisywano cudowną moc. Między innymi używano ich do leczenia chorób i ran. Pocierano nimi dziewięciokrotnie chore części ciała a następnie zwracano je Olafowi, aby odzyskiwały swą moc (Marecki, Rotter 2009: 473).

Notabene w najmniejszym stopniu nie kłóci się z taką interpretacją łączenie miniaturowych toporów typu II z symboliką łodzi, co zasugerował w oparciu o znalezisko z Kałdusa Wojciech Chudziak (2004: 193), łódź bowiem również należy do atrybutów św. Olafa (Marecki, Rotter 2009: 472). Postać wojowniczego władcy chrystianizatora - znanego w Skandynawii i na Rusi za życia, a po śmierci czczonego jako męczennika (Panasiewicz, Wołoszyn 2002: 262; Jackson 2010; Kucypera i in. 2011: 48-49; Gąssowska 2012) - doskonale nadawała się na patrona drużynników książęcych i ich synów, miniaturowe brązowe topory zaś na jej znak, a może nawet wyróżnik wojów wareskiego pochodzenia (Makarov 1992: 51; Wołoszyn 2006: 598-602). Zauważyć trzeba, że rolę w propagowaniu kultu Olafa poza granicami Norwegii odegrać mógł jego przyrodni brat Harald III Srogi Sigurdsson, zięć Jarosława Mądrego i władca norweski, który przez długi czas był najemnikiem na Rusi i w Bizancjum. Podkreślić należy, że w samej Norwegii cześć dla

9 Olaf II Haraldsson (995-1030) był w latach 1016-1028 królem Norwegii. Zginął 29 lipca I030 r. w bitwie z wojskami Knuta Wielkiego (Duńczycy i norweska opozycja antyolafowska) pod Stiklestad. 
męczennika upowszechniła się bardzo wcześnie, o czym świadczy przekaz Glalognskvidy Pórarina z pierwszej połowy lat 30. XI w., której fragmenty warto zacytować:

$$
\begin{gathered}
\text { En herr manns, } \\
\text { Es heilagr es } \\
\text { konungr sjalfr, } \\
\text { krýpr at gagni, } \\
\text { ok beiðendr } \\
\text { blindir sœkja } \\
\text { pjóðan máls, } \\
\text { en paðan heilir. }
\end{gathered}
$$

Tłum ludzi klęczy modląc się o pomoc i wstawiennictwo tam spoczywa święty król; i ślepi żebracy szukają rozmowy z królem i wychodzą stamtąd uleczeni.

$$
\begin{gathered}
\text { Bið Áleif, } \\
\text { at unni pér } \\
\text { (hann’s goðs maðr) } \\
\text { grundar sinnar; } \\
\text { hann of getr } \\
\text { af goði sjolfum } \\
\text { ár ok frið } \\
\text { ọllum mǫnnum. }
\end{gathered}
$$

Módl się do Olafa, który obdarzył Cię swoją ziemią, on jest człowiekiem Boga (świętym), Bóg obdarza jego samego dobrami i pokojem dla wszystkich ludzi ${ }^{10}$.

Mniejszej uwagi wymagają pozostałe przedmioty, nie wydaje się bowiem, aby pełniły funkcję znacząco inną niż użytkowa (broń, pojemnik na napój lub pokarm i naczynie do picia), choć mogły być też świadectwami statusu społecznego zmarłych.

Grot włóczni ${ }^{11}$ (MAK/3664; ryc. 8: 2; 9: 2) wykuto z żelaza (ryc. 10). Jest to okaz średniej wielkości, z lancetowatym liściem o wyraźnych, zatępionych na krótkim odcinku, dolnych krawędziach i przekroju o słabo zaznaczonej czworoboczności (niemal soczewkowaty, spłaszczony). Zachował się w dobrym stanie (szczerby na

10 Cytat za Jakubem Morawcem, który jest też autorem przekładu (Morawiec 2013: 298-299).

11 Bibliografia zabytku: Katalog... 1856: 16-17; Nadolski 1954: 182-183; Piaskowski 1960: 198-199, 201, 205, 217-218, 220, 222, 224; Liwoch 2014b: 326, 333; 2016: 52. 


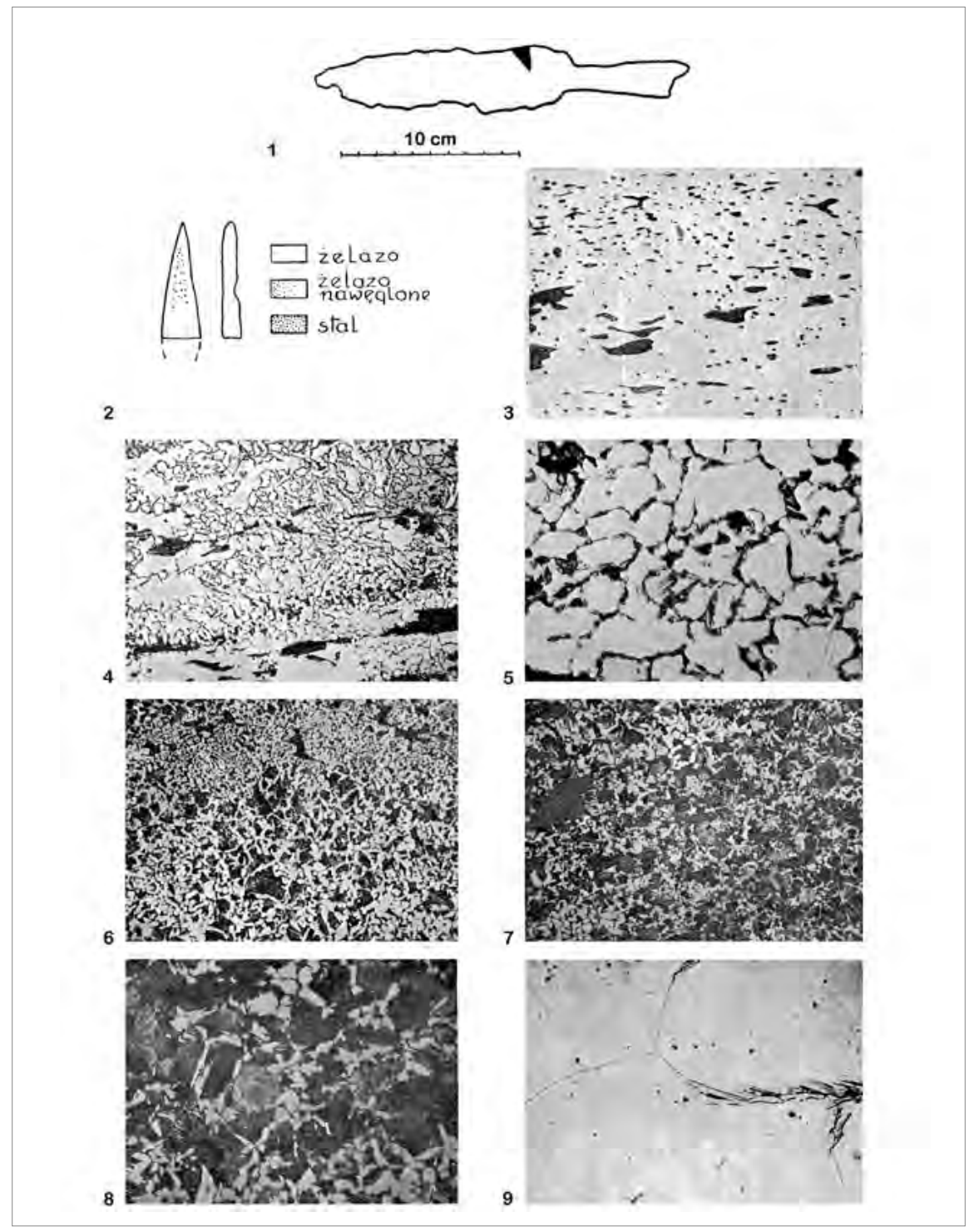

Ryc.10. I - grot włóczni z Siemienic (MAK/3664); 2 - technologia grotu; 3 - wtrącenia żużla w liściu grotu, nietrawiony; 4 - struktura słabiej nawęglonej części liścia grotu: ferryt i perlit oraz wtrącenia żużla, trawiony azotalem; 5 - struktura słabiej nawęglonej części liścia grotu pod większym powiększeniem: ferryt i perlit oraz wtrącenia żużla, trawiony azotalem; 6 - struktura silniej nawęglonej części liścia grotu: ferryt i perlit, trawiony azotalem; 7 - struktura silniej nawęglonej części liścia grotu: ferryt i perlit oraz liczne wtrącenia żużla, trawiony azotalem; 8 - struktura silniej nawęglonej części liścia grotu pod większym powiększeniem: perlit i ferryt, trawiony azotalem; 9 -struktura tulei grotu: ferryt, trawiony azotalem (wg Piaskowski 1960: 198, 20I, 217-2I8). 
ostrzu, brak dolnej części tulei, ubytki powierzchniowe i jeden na wylot; próbki do badań metalograficznych - po jednym trójkątnym wycięciu na liściu i tulei). W konserwacji przybrał barwę czarną z lekkim połyskiem. Ma wymiary: długość - 21,0 cm, długość tulei $-6,5 \mathrm{~cm}$, największa szerokość liścia $-3,7 \mathrm{~cm}$, najmniejsza szerokość tulei $-1,6 \mathrm{~cm}$, średnica tulei u wylotu (zachowana) $-2,2 \mathrm{~cm}$, grubość liścia (pośrodku) - 0,4 cm, ciężar (zachowany) - I28,5 g. Zalicza się do typu v (w formie bliskiej typowi Iv) wg Andrzeja Nadolskiego, który jest liczny, zróżnicowany wewnętrznie i szeroko datowany (Nadolski 1954: 54-55). Nowsze prace bronioznawcze (np. Strzyż 2006: 68-7I) nie przynoszą zasadniczych zmian w wiedzy o podobnych grotach w Polsce. Wydaje się jednak, że w wypadku zabytku siemienickiego najwłaściwsze będzie zawężenie chronologii do XI, ewentualnie pierwszej połowy XII w. ${ }^{12}$

Ciekawostką jest, że grot ten pomyłkowo uznano za pochodzący z wczesnej epoki żelaza z Siemianic w pow. kępińskim. Jerzy Piaskowski przeprowadził badania metaloznawcze tego i ponad dwudziestu rozmaitych zabytków żelaznych z okresów halsztackiego i lateńskiego. Pokazały one - co nie zaskakuje - że odrębny typ metalu reprezentuje grot wtóczni z Siemianic [Siemienic - R.L.], wykonany z miękkiej stali o nierównomiernym nawegleniu; metal posiadat wysoka zawartość fosforu (Piaskowski 1960: 206) ${ }^{13}$.

Wiadro ${ }^{14}(\mathrm{MAK} / 3664 ;$ ryc. $8: 3 ; 9: 3)$ zachowało się szczątkowo w postaci wykutych z żelaza: kabłąka, uchwytu płytkowego i fragmentów obręczy. Pozostałości świadczą, iż było ono niewielkie. Miało zapewne formę ściętego stożka z drewnianych klepek. Kabłąk jest nieco zniekształcony. Ma postać mniej więcej kolistego w przekroju pręta zwężającego się ku wygiętym pod kątem około $90^{\circ}$ końcom. Jego wymiary to: rozpiętość - $13,3 \mathrm{~cm}$, wysokość $-6,6 \mathrm{~cm}$, średnica pośrodku - 0,4 cm, ciężar - I4,2 g. Cztery niewielkie odcinki żelaznej płasko-wypukłej taśmy były niegdyś częścią obejmy. Ich wymiary to odpowiednio: długość - 6,5; 5,I; 5,0 i 4,7 cm, szerokość - 0,4; 0,5; 0,5 i 0,4 cm, grubość wszystkich - 0,3 cm,

12 Na marginesie zauważyć można, że groty włóczni bywały wkładane nie tylko do grobów męskich, ale także do kobiecych, o ile poprawna jest analiza antropologiczna szczątków ludzkich z obiektów 24 w Łączynie Starym i 37/38 w Tańsku-Przedborach (Kordala 2006: I43). Wspomnieć też warto o ciekawych uwagach Tomasza Kurasińskiego (2014) na temat deponowania włóczni w grobach.

13 Według J. Piaskowskiego:

[...] wykonany byt z metalu o nierównomiernym nawegleniu; zawartość fosforu byta bardzo wysoka. Metal byt silnie zanieczyszczony żużlem (ryc. 1o:3). W próbce wyciętej z liścia zawartość wegla zmieniata się od ok. o, I\% C (ryc. 10: 4, 5) do ok. o,3\% C (ryc. 1o: 6-8). Natomiast w próbce wyciętej z tulei wystąpit gruboziarnisty ferryt (ryc. 10: 9).

Numerację rycin zmieniono, dostosowując ją do niniejszego artykułu.

14 Bibliografia zabytku: Katalog... 1856: I6 (?); Liwoch 2014b: 326, 333 . 
ciężar - I,7; I,8; I,5; I,4 g (łączny 6,4 g). Uszkodzona płytka uchwytu mocującego kabłąk do kadłuba naczynia jest płaska, $\mathrm{z}$ wałkowatym zgrubieniem na górze po jednej (zapewne zewnętrznej) stronie i z otworem poniżej niego. Ma wymiary: wysokość - I,7 cm, szerokość - I, cm, grubość - O,I cm, grubość z wałkiem - 0,4 cm, średnica otworu - 0,4 cm, ciężar - I,I g. Drewniane wiadra z żelaznymi okuciami i kabłąkiem są najliczniej znajdowaną w grobach grupą naczyń. Ich problematykę omówili Andrzej Janowski i Tomasz Kurasiński (2008: 63-72).

Naczynie ${ }^{15}$ miniaturowe (MAK/3664; ryc. 8: 4; 9: 4) ulepiono z gliny z domieszką piasku, obtoczono i wypalono w atmosferze tlenowej. Ma gładką podstawę, brzusiec zaokrąglony, z dwoma poziomymi szerokimi żłobkami wzbogaconymi dookolnym ornamentem odciskanym i podobnym dookolnym szeregiem małych odcisków na stosunkowo ostrym przejściu do szyjki, która jest cylindryczna, gładka, z brzegiem lekko wychylonym. Jego powierzchnia jest gładka, koloru brązowego z czarniawymi przebarwieniami. Zachowało się w średnim stanie (wyklejone $\mathrm{z}$ dużych ułamków, niemal I/s to gipsowe uzupełnienie, część brzegu uszkodzona). Ma wymiary: wysokość $-4,2 \mathrm{~cm}$, średnica dna $-3,8 \mathrm{~cm}$, średnica brzuś$\mathrm{ca}-5,3 \mathrm{~cm}$, średnica szyjki - 4,0 cm, średnica wylewu (rekonstruowana) $-4,2 \mathrm{~cm}$. Zaliczyć je można do typu z cylindryczną szyjką, który często występuje na Mazowszu, a szczególnie na tamtejszych cmentarzyskach. Zestawienie przypadków współwystępowania naczyń o cylindrycznej szyjce z monetami pozwala określić ich chronologię na XI w., jednak na podstawie danych stratygraficznych z różnych stanowisk przypuszczać można, że naczyń takich używano od x do XIII w. (Musianowicz 1952: 349, 365-366). Zagadnienie naczyń ceramicznych - drugiej pod względem liczebności grupy pojemników wkładanych do wczesnośredniowiecznych grobów - zostało niedawno przeanalizowane przez A. Janowskiego i T. Kurasińskiego (2008: 72-77).

Grot włóczni ${ }^{16}$ (nr inw. MAK/3478; ryc. II: I, 2) został wykuty z żelaza. Jest niewielki, krępy. Ma liść bardzo wydłużony sercowaty, z dolnymi krawędziami wyraźnymi, zatępionymi na krótkim odcinku, ze słabo zaznaczoną w przekroju czworobocznością (niemal soczewkowaty, spłaszczony). W tulei znajduje się otwór na gwóźdź i drobny ułamek gwoździa po drugiej stronie. Jest bardzo dobrze zachowany (szczerby na ostrzu i krawędzi tulei, ubytki powierzchniowe i kilka na wylot). Po konserwacji ma kolor czarny. Jego wymiary to: długość $-15,7 \mathrm{~cm}$, długość tulei - 5,I cm, największa szerokość liścia - 3,5 cm, najmniejsza szerokość tulei - I,2 cm, średnica tulei u wylotu $-2,2 \mathrm{~cm}$, światło tulei u wylotu $-1,9 \mathrm{~cm}$

15 Bibliografia zabytku: Katalog... 1856: 16-17; Liwoch 2014b: 326-327, 333; 2016: 83.

16 Bibliografia zabytku: Wawrzeniecki 1908: 94; Nadolski 1954: 182-183, 262; Liwoch 2016: 5I. 


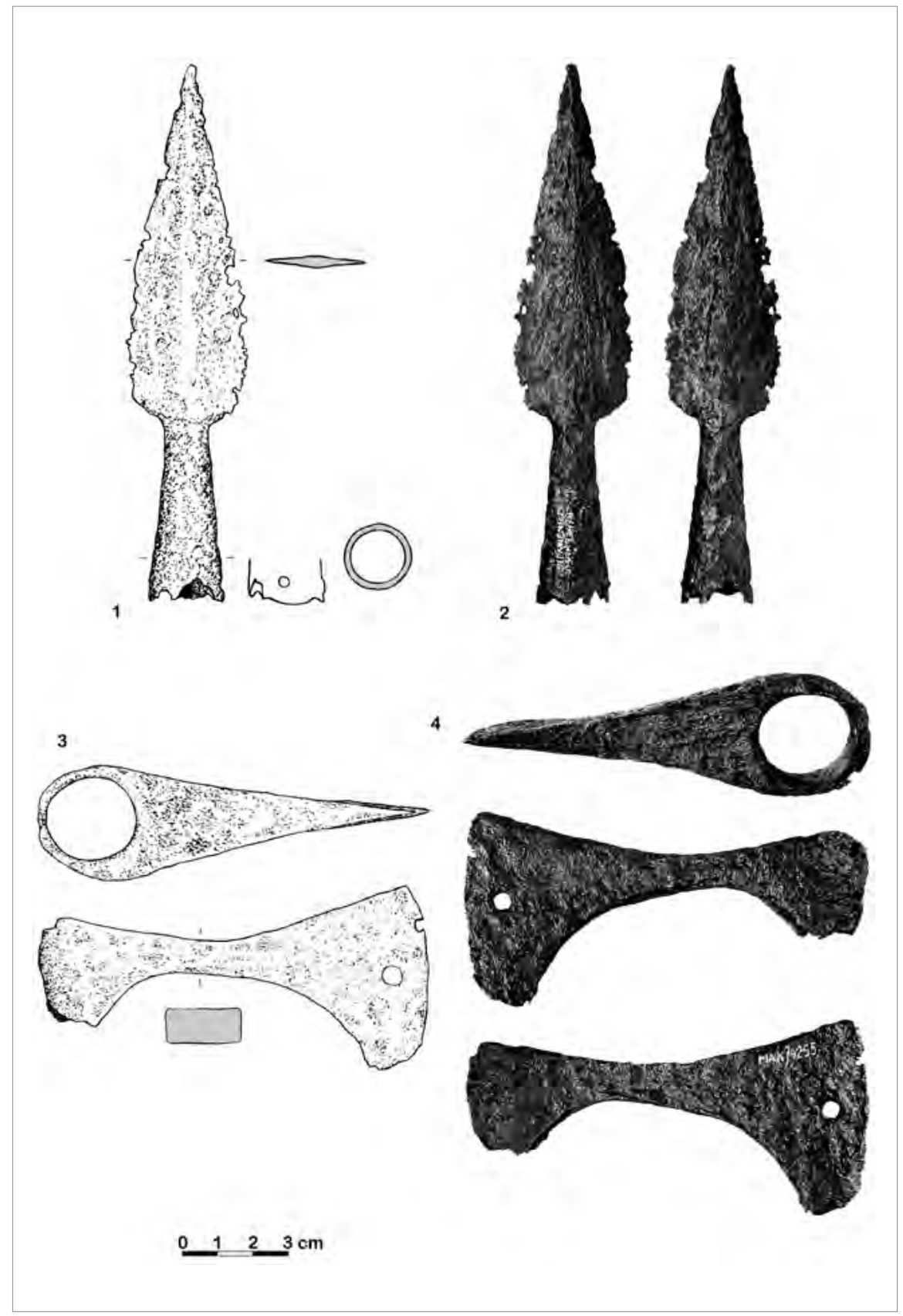

Ryc.11. Zabytki z grobu (grobów?) kamiennego w Siemienicach (odkrycie być może z 1906 r.): I-2 - żelazny grot włóczni; 3-4-żelazny topór (rys. W. Rumian, fot. A. Susuł). 


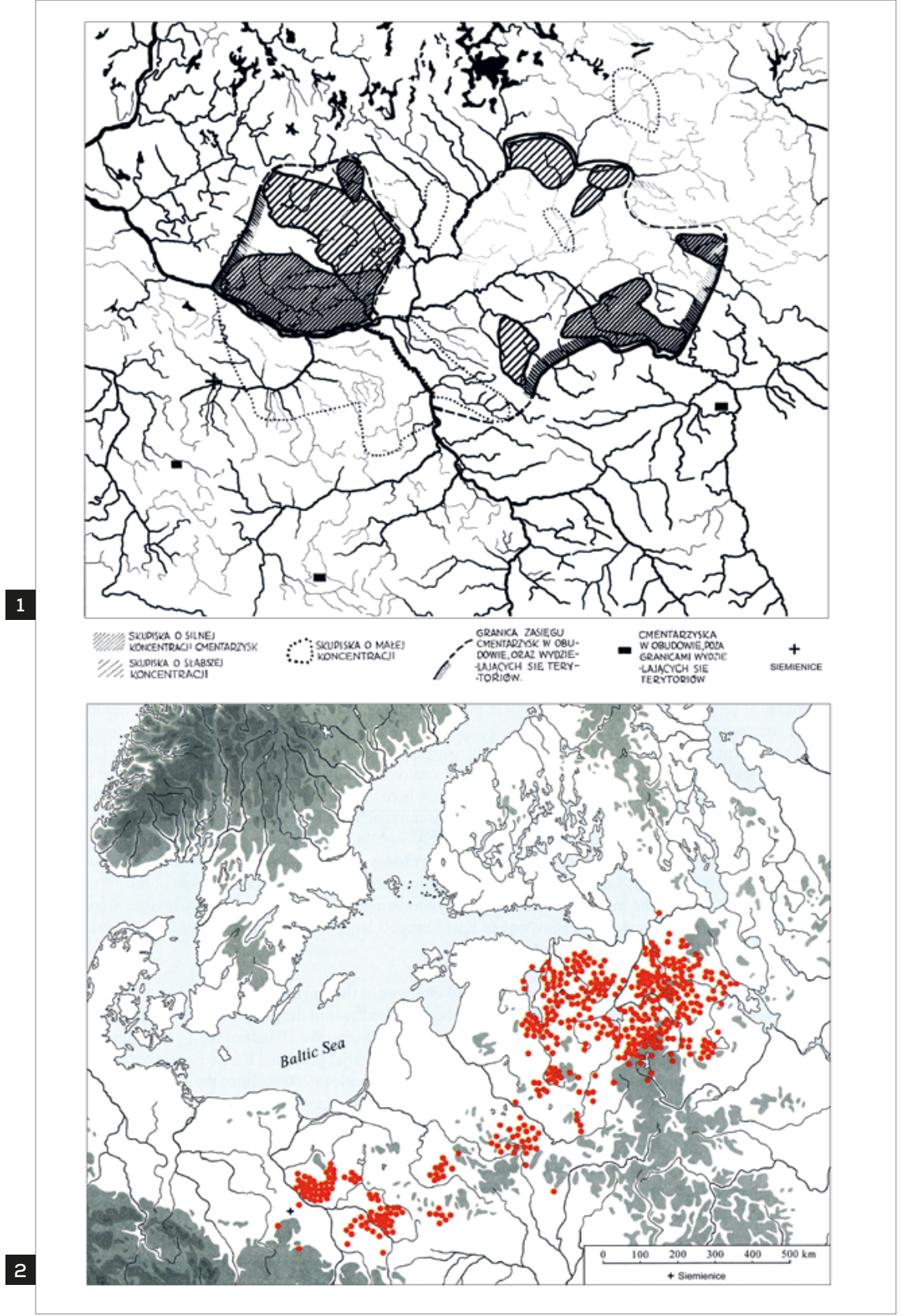

Ryc.12. I - zasięg występowania cmentarzysk w obudowach i bez obudów na terenie Mazowsza i Podlasia; 2 - rozmieszczenie grobów typu „żalnik” ( - wg Rauhut 197I: 453; 2 - wg V.V. Sedova za Valk 20I2: 739). 


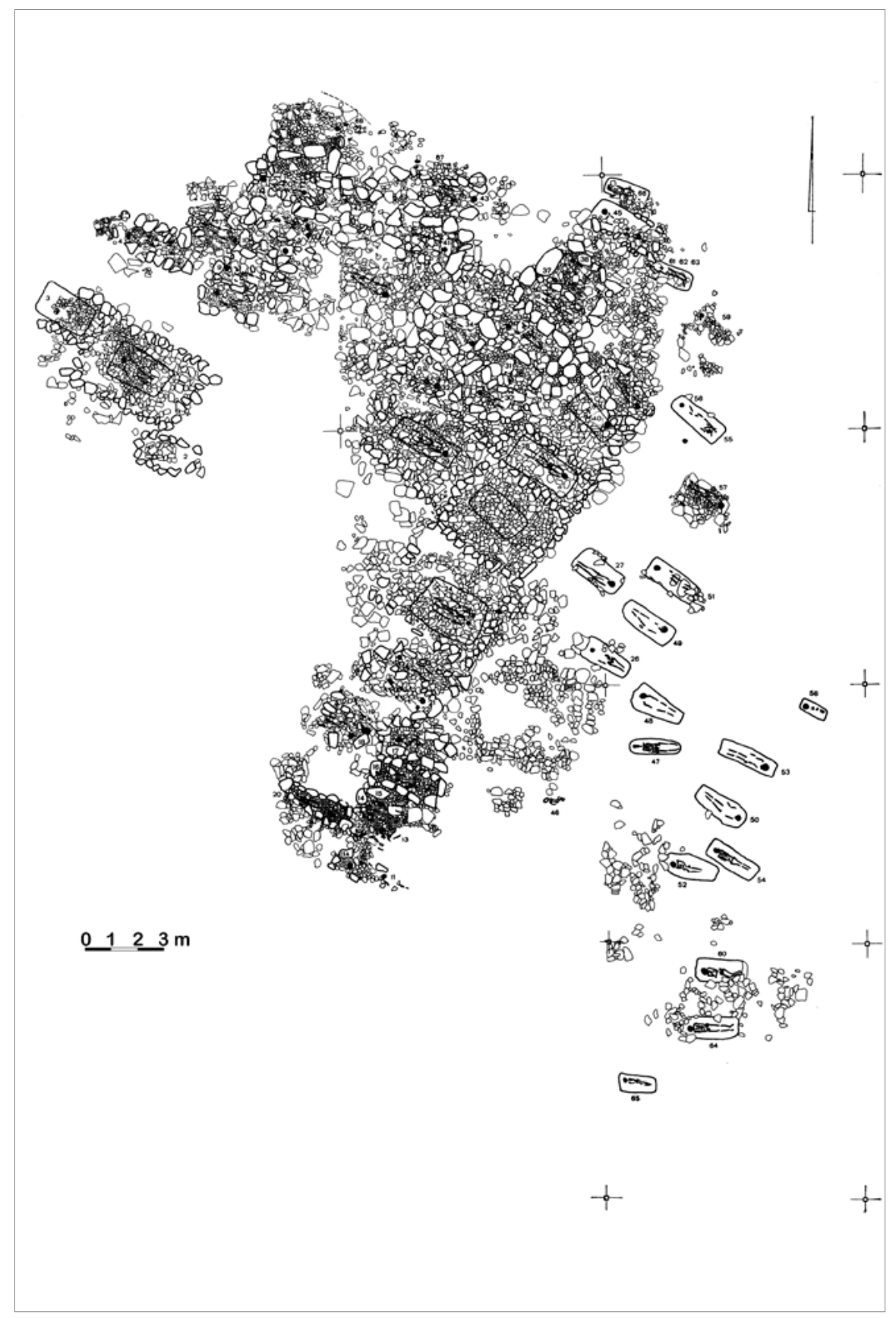

Ryc.13. Plan cmentarzyska (stanowisko Żal) w Starym Łączynie w pow. mławskim (wg Rauhut, Długopolska 1972: 322). 


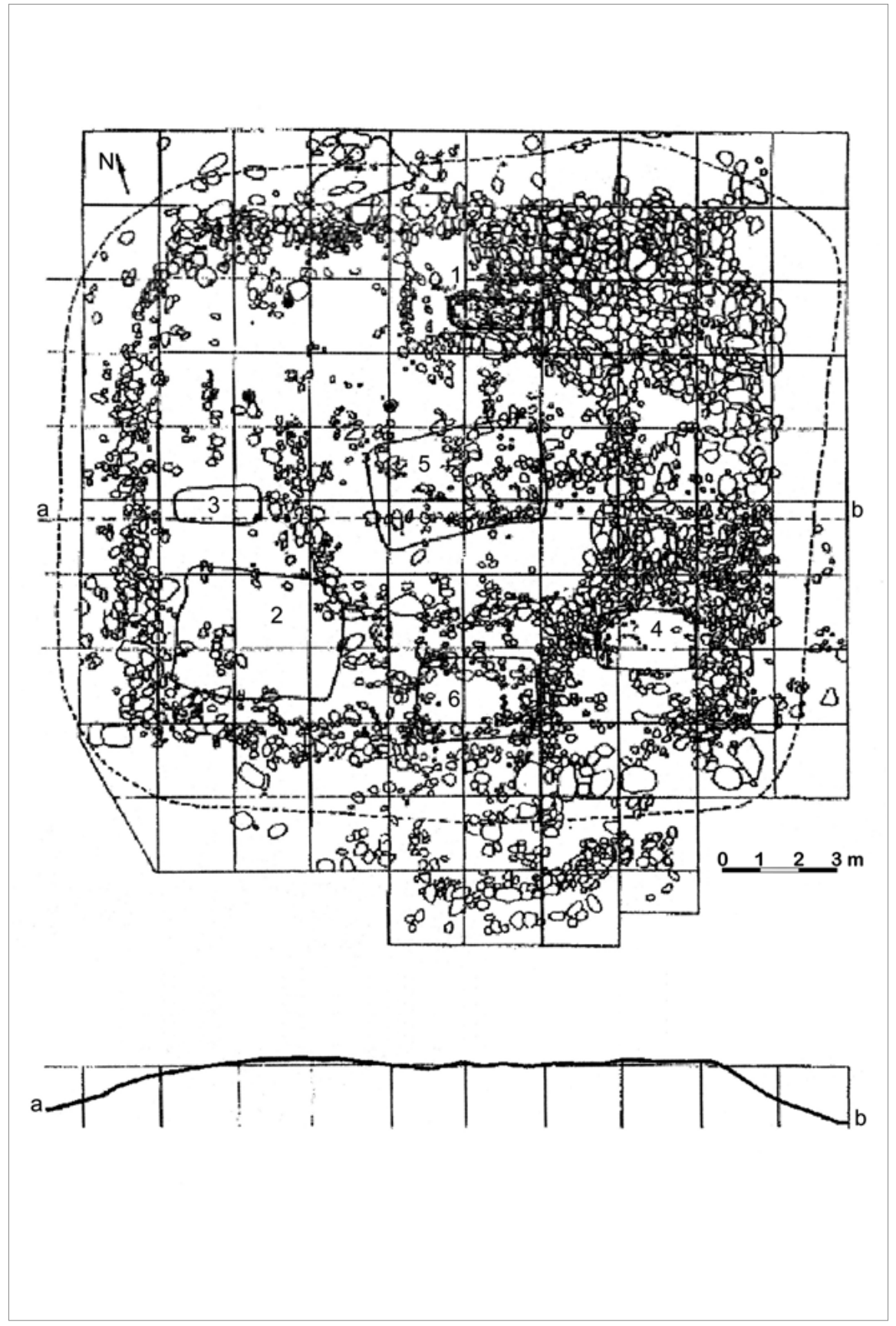

Ryc.14. Plan cmentarzyska w Udraju (stanowisko Udraj II) w obw. nowogrodzkim (Rosja), $70 \mathrm{~km}$ na północny zachód od Nowogrodu (wg Platonova 1998: 372). 


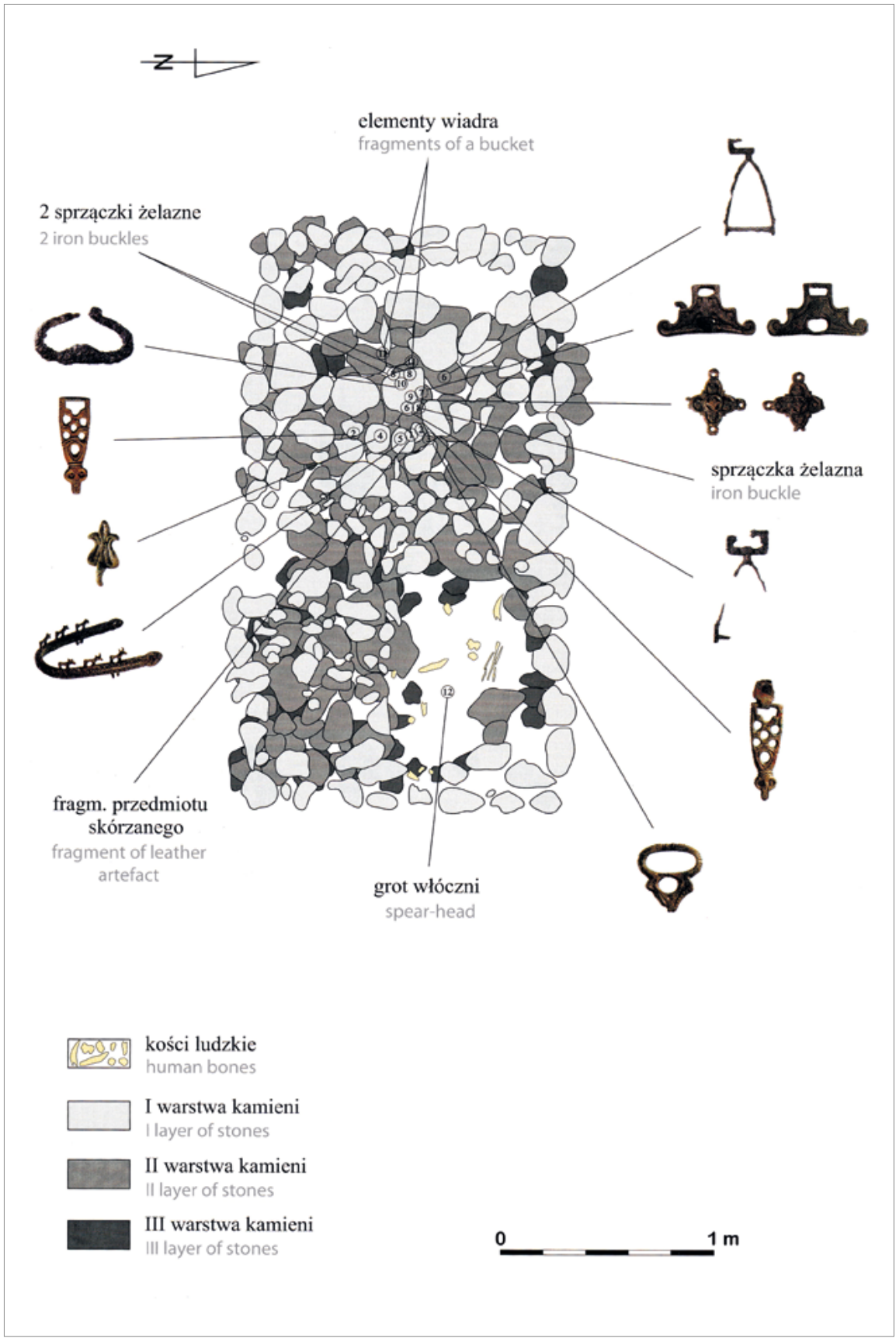

Ryc.15. Przykład grobu kamiennego (grób Io) z Lutomierska (wg Grygiel 20I4: 693). 
grubość liścia (pośrodku) - 0,4 cm, ciężar - 62,3 g. Należy do typu IV wg A. Nadolskiego, który datowany jest w zasadzie na XI w. (Nadolski 1954: 54; Strzyż 2006: 68). Żeleźce topora ${ }^{17}$ (nr inw. MAK/4255; ryc. II: 3, 4) wykuto z żelaza. Jest małe, lekko opuszczone w stosunku do osi toporzyska. Ma ściętą, wąską brodę (słabo zaznaczone przejście między ostrzem a podstawą brody), otwór przy łagodnie łukowatym ostrzu, osadę z niewielkimi wąsami (bez kapturka), o świetle niemal kolistym, obuch zaś zaokrąglony. Zachowało się w dobrym stanie (szczerba na ostrzu, uszkodzone wąsy, ubytki powierzchniowe). Po zakonserwowaniu jest barwy ciemnosrebrzystej z połyskiem. Ma wymiary: długość - II,I cm, wysokość ostrza $-5,4 \mathrm{~cm}$, średnica otworu (zawieszki) $-0,5 \mathrm{~cm}$, najmniejsza wysokość szyi - I,o cm, wysokość wąsów (zachowana) - 3,I cm, wysokość obucha $-2,2 \mathrm{~cm}$, szerokość osady $-3,3 \mathrm{~cm}$, światło osady $-2,5 \mathrm{~cm}$, ciężar $-158,5 \mathrm{~g}$. Zalicza się do typu vc wg A. Nadolskiego (typ 5 wariant IB.5.2 wg Piotra N. Kotowicza), z którego większość datowanych okazów pochodzi z XI w., choć są też X-i XII-wieczne, a może także z XIII w. (Nadolski 1954: 46; Kotowicz 20I8: 77-78).

Przedstawiane zabytki ze zbiorów dawnych MAK-u znaleziono w Siemienicach w trakcie prac rolnych niszczących cmentarzysko kamienne (por. przypisy 4 i 5 ). Można przypuszczać, że składały się na inwentarz przynajmniej dwu grobów. Nie ma pewności, jaką miarą posługiwał się W. Krasiński, który podał widoczną bez wykopalisk wielkość cmentarzyska w połowie XIX w., jednak domyślać się trzeba, że nowopolską, w której na mórg składało się 300 prętów (Kula 2004: 275, 277). Według Stownika geograficznego Królestwa Polskiego... (Stownik geograficzny... I885: 677) mórg, czyli 300 prętów, to 56,017 a, zatem kilkadziesiąt prętów to obszar mniejszy niż ı8,67 a (ı०० prętów). O powierzchni bruku grobowego niszczonego pół stulecia później nie ma żadnej informacji. Zabytki ruchome pozwalają datować $^{18}$ groby, a zatem pośrednio całe nekropoliczne stanowisko ${ }^{19}$, na stosunkowo

17 Bibliografia zabytku: Wawrzeniecki 1908: 94; Nadolski 1954: 170-171, 258; Kotowicz 2014: 158, 372; 2018: 78; Liwoch 2016: 102.

18 Pamiętać trzeba, iż W. Krasiński wzmiankował znalezione w grobie [...] dwa pieniążki zlepione razem, iak twiérdza znawcy z czasów Wtadystawa Jagietty [...], co nasuwa przypuszczenie, że były to denary Władysława I Hermana (ok. IO42-IO79-IIO2) z napisem VLADISLAVS w otoku na awersie. Wspomnieć też można o znalezionym w Siemienicach - czy na tym samym cmentarzysku? - mieczu (Sikora 2009: IIo).

19 Dość niejasna wzmianka M. Wawrzenieckiego, iż [...] okazaty się urny w liczbie s, które pokruszono, w urnach byty drobne kostki (palone) [...], która mogłaby sugerować ciałopalny obrządek pogrzebowy na siemienickim cmentarzysku, traci na znaczeniu wobec wiadomości W. Krasińskiego, który najpewniej widział [...] czaszkę ludzką kilkakrotnie rozbitą, będącą pozostałością pochówku szkieletowego. Nie można wykluczyć, iż M. Wawrzeniecki wspomniał o cmentarzysku z okresu wpływów rzymskich (również z konstrukcjami kamiennymi), które zapewne znajdowało się w Siemienicach (por. Katalog... 1856: 17). 
niedługi okres od około połowy XI do początku XII w. Cmentarzysko siemienickie ma liczne odpowiedniki (por. ryc. I2: I, 2) na nieodległym Mazowszu (np. Żal w Starym Łączynie, ryc. 13; Rauhut, Długopolska 1972) i na Podlasiu (np. Mogitki w Czarnej Wielkiej; Bieńkowska i in. 2013; Średniowieczne... 2014), ale też w innych regionach, m.in. na północno-zachodniej Rusi (np. Udraj II, ryc. I4; Platonova 1998; 2017). Wydaje się, że impuls do konstruowania grobów i cmentarzy kamiennych wyszedł właśnie z Północy i Wschodu, tj. od przybyłych do Polski przez Ruś wojowników skandynawskiego pochodzenia, z którymi łączyć można i starsze ${ }^{20}$, i młodsze - w tym siemienickie - obiekty. Te ostatnie są prawdopodobnie śladem kolejnej fali przybyszów stamtąd, a następnie kontynuacją zwyczaju przez ich spolonizowanych potomków i/lub naśladownictwem - może rodzajem snobizmu - przez ludność autochtoniczną ${ }^{21}$. Podobne przypuszczenie wyraziła w oparciu o znajdowane w grobach kamiennych przedmioty pochodzenia wareskiego lub rusko-wareskiego Teresa Kiersnowska (2000: 236-237), która zjawisko cmentarzysk kamiennych tłumaczy

[...] osadzaniem na Mazowszu północnym wojowników warego-ruskich wchodzących w skład wojsk Jarosława Mądrego, który przybył na Mazowsze, jak potwierdzająźródła pisane, niosąc pomoc swemu szwagrowi Kazimierzowi Odnowicielowi w walce z Mazowszanami. W zamian za ujarzmienie Mazowsza dostali ci wojownicy nadania ziemi zbuntowanego ludu. Asymilacja z miejscową ludnością mogła nastąpić dość prędko, łącznie z zatratą swojego języka; przy podboju Normandii nastąpiło to już w drugim pokoleniu, najtrwalsza jednak była sprawa wierzeń uwidoczniona w sposobie chowania zmarłych.

Wspomniane przez badaczkę źródła to tylko Powieść minionych lat, w której latopisarz odnotowat:

Roku 6555 [1047]. Jarosław poszedł na Mazowszan i zwyciężył ich, i kniazia ich zabił, Mojsława [Miecława], i poddał ich Kazimierzowi (Powieść... 1999: 12I),

20 Przykładem takiego wczesnego - z I. połowy xI w. - cmentarzyska jest birytualna nekropola z różnymi formami grobów, w tym z grobami kamiennymi (por. ryc. I5), z Lutomierska w pow. pabianickim.

21 Zaznaczyć trzeba, że w odniesieniu do grobów kamiennych z międzyrzecza Bugu i Narwi rację może mieć M. Dzik (2015), który widzi w nich modyfikację wcześniejszego lokalnego zwyczaju sypania kurhanów z rdzeniami kamiennymi i zaprzecza ich pokrewieństwu kulturowemu z podobnymi grobami z północnego Mazowsza (por. uwagi Katarzyny Skrzyńskiej 2019: 286-287). 
ponieważ anonimowy kronikarz w Polsce opisał wydarzenia z połowy XI w. zupełnie inaczej:

Był bowiem pewien człowiek, imieniem Miecław, cześnik [...] do takiej posunął się hardości i pychy, że odmawiał posłuszeństwa Kazimierzowi, a nadto z bronią w ręku i podstępem stawiał mu opór. Lecz Kazimierz, oburzony, że sługa ojca i jego własny siłą zatrzymuje Mazowsze, i przekonany, że gdyby nie dochodził swych praw, groziłaby mu wielka szkoda i niebezpieczeństwo, zebrał nieliczną wprawdzie, lecz zaprawioną w walkach garść wojowników i stoczył zbrojnie bitwę [ı047 r.], w której Miecław poległ, a on tryumfalnie zdobył zwycięstwo, pokój i cały kraj. Miała tam nastąpić ogromna rzeź Mazowszan [...] W owej zaś bitwie mieli Mazowszanie 30 sprawionych hufców, podczas gdy Kazimierz posiadał zaledwie 3 pełne hufce wojowników [...] (Kronika... 1996: 46-47).

Jednak udział Rusinów i najemników wareskich raczej nie budzi obecnie wątpliwości archeologów. Uzasadniony jest domysł, że w ramach wynagrodzenia za służbę i ewentualnego zabezpieczenia swego panowania na północnym wschodzie państwa książę Kazimierz Odnowiciel osadził część obcych oddziałów na Mazowszu oraz - jak świadczy przykład Siemienic w Ziemi Łęczyckiej - poza jego granicami ${ }^{22}$. Osobnym, ale istotnym, jest zagadnienie religii pochowanych w grobach kamiennych. Nie można zgodzić się z Markiem Duliniczem (2009: 395), dla którego groby te [...] byty częścia świata ludzi tkwiacych korzeniami w wierzeniach pogańskich. Wprost przeciwnie - należały do pierwszych pokoleń zdeklarowanych chrześcijan (por. Valk 20I2), czego potwierdzeniem jest cmentarzysko Udraj II w rejonie Nowogrodu $\mathrm{z}$ datowanym na pierwszą połowę XI w. grobem $\mathrm{KH}-5$, w którym znaleziono srebrny krzyżyk, oraz omawiany grób siemienicki z miniaturowym toporem - „medalikiem” św. Olafa. Wydaje się, że zmarli z najstarszych grobów kamiennych w Polsce - w tym i z mogił w Siemienicach - byli nosicielami zjawiska kulturowego określanego mianem kultury drużynnej ${ }^{23}$ w jego schyłkowej fazie, już po dwu zasadniczych etapach (I etap w IX/X - drugiej połowie X w., II etap w końcu X - pierwszej połowie XI w.) wyodrębnionych przez Aleksandra A. Fetisova (20I2: 409-4II). Zjawisko to w różnym nasileniu wystąpiło w wielu krajach Europy, w tym także

22 Autor nie wnika w zagadnienie, kiedy ustaliły się granice poszczególnych dzielnic monarchii piastowskiej.

23 Zdaniem autora forma grobów była w tym wypadku manifestacją pozycji społecznej pochowanych osób, a łatwość zebrania polnych kamieni na bruki ostentację tę znacząco ułatwiała. Szerzej funkcję i symbolikę grobów kamiennych omówił M. Dzik (2014; tam literatura), który jednak dopatruje się w tego rodzaju mogiłach odzwierciedlania idei domu zmarłego. 
w Polsce, ale szczególnie ważne było dla Rusi, gdzie jest doskonale obserwowalne archeologicznie (por. Fetisov 20I2). Odnotować należy, iż cmentarz kamienny w Siemienicach założono w bliskości Łęczycy - jednego z ważniejszych grodów państwa, w którym obecność przybyszów ze Wschodu i Północy w XI-XII w. nie budzi wątpliwości (por.: Początki... 2014: 95-652; Grygiel 2014: 746) - co zapewne nie było przypadkiem i wiązało się z polityką władców Polski.

\section{Bibliografia}

\section{Źródła}

Kronika polska (Anonima tzw. Galla), przeł. R. Grodecki, oprac. M. Plezia, Wrocław 1996. Powieść minionych lat, przeł., oprac. F. Sielicki, Wrocław 1999.

\section{Opracowania}

Bieńkowska A., Dzik M., Piasecka K. (2013), Średniowieczne cmentarzysko w Czarnej Wielkiej stan. I, woj. podlaskie (badania I95I-1978), t. I, Muzeum Podlaskie, Białystok.

Chochorowska E. (200I), Zbiory krakowskiego Muzeum Archeologicznego dawniej i dzis, „Materiały Archeologiczne”, 32, s. 13-18.

Chudziak W.(2004), Niektóre okoliczności przeptywu rzeczy i idei we wczesnym średniowieczu - instruktywne przyktady „chetmińskie”, [w:] S. Moździoch (red.), Wędrówki rzeczy i idei w średniowieczu, Wydawnictwo Instytutu Archeologii i Etnologii Polskiej Akademii Nauk, Wrocław (Spotkania Bytomskie, 5), s. 183-197.

Darkevič V.P.(196I), Topor kak simvol Peruna v drevnerusskom âzyčestve, „Sovetskaâ arheologiâ", 4, S. 91-102.

Dulinicz M. (2000), Mazowsze w x wieku, [w:] H. Samsonowicz (red.), Ziemie polskie $w X$ wieku $i$ ich znaczenie w ksztattowaniu się nowej mapy Europy, Uniwersitas, Kraków, s. 199-220 + ilustracje.

Dulinicz M. (2009), Wczesnośredniowieczny przetom w obrzadku pogrzebowym na Mazowszu, [w:] S. Moździch (red.), Stare i nowe wśredniowieczu. Pomiędzy innowacją a tradycja, Wydawnictwo Instytutu Archeologii i Etnologii Polskiej Akademii Nauk. Oddział, Wrocław (Spotkania Bytomskie, 6), s.379-399.

Dzik M.(2OI4), Uwagi o funkcji i symbolice konstrukcji wczesnośredniowiecznych grobów w obudowach kamiennych, [w:] T. Kurasiński, K. Skóra (red.), Grób w przestrzeni, przestrzeń w grobie. Przestrzenne uwarunkowania w dawnej obrzędowości pogrzebowej, Łódzkie Towarzystwo Naukowe, Łódź (Acta Archaeologica Lodziensia, 60), s. 87-IOI.

Dzik M. (2015), Early Medieval Stone Barrows in the Area between the Bug and the Upper Narew Rivers, „Archaeologia Polona”, 48, 2010, s. I2I-138. 
Fetisov A.A. (2012), “Družinnaâ kul'tura” Drevnej Rusi, „Drevnejšie gosudarstva Vostočnoj Evropy. 2010 god. Predposylki i puti obrazovaniâ Drevnerusskogo gosudarstva”, s. $406-436$.

Fûredi A., Tûrk A., Zagorhidi-Cigan' B. (2018), Amulety-toporiki v materiale Karpatskogo bassejna XI-XIII vekov. Arheologičeskie nablûdeniâ o svâzah Vengrii s Rus'û vo vremâ rannego perioda dynastii Arpadov, [w:] A. Türk, A.S.Zelenkov (red.), III-j Meždunarodnyj mad' ârskij simpozium, Budapešt, 6-Io iûnâ 2oI 6 g. / 3. Nemzetközi Korai Magyar Történeti és Régészeti Konferencia, Budapest, 20I6. Június 6-Io, Budapest (Studia ad Archaeologiam Pazmaniensia, I2), s. 483-514.

Gąssowska M. (2012), Der Heilige Olaf und Holmgård - Novgorod als Grenzraum zwischen Ost und West im II.-I2. Jahrhundert, [w:] M. Salamon i in. (red.), Rome, Constantinople and Newly-converted Europe. Archaeological and Historical Evidence, t. I, Uźródet Europy Środkowo-Wschodniej / Frühzeit Ostmitteleuropas, t. I.I, Wydawnictwo Instytutu Archeologii i Etnologii Polskiej Akademii Nauk, Kraków-LeipzigRzeszów-Warszawa, s. 263-273.

Grygiel R. (2014), Cmentarzysko wareskich drużynników w Lutomiersku, [w:] R. Grygiel, T. Jurek (red.), Początki Eęczycy, Muzeum Archeologiczne i Etnograficzne, Łódź, s. $679-757$.

Haisig M. (1952), Bolestaw Podczaszyński. Sfragistyk i archeolog, Muzeum Śląskie, Wrocław.

Jackson T.N.(2010), The Cult of St Olaf and Early Novgorod, [w:] H. Antonsson, I. Garipzanov (red.), Saints and their Lives on the Periphery. Veneration of Saints in Scandinavia and Eastern Europe (c. 1000-I200), Brepol, Turnhout-Abingdon, S. 147-167, https://doi.org/IO.I484/M.CURSOR-EB.3.4592

Janowski A., Kurasiński T.(2008), (Nie)militarne naczynia. Fakty i mity, [w:] W. Świętosławski (red.), Nie tylko broń. Niemilitarne wyposażenie wojowników w starożytności iśredniowieczu, Łódzkie Towarzystwo Naukowe, Łódź (Acta Archaeologica Lodziensia, 54), s. 6I-88.

Katalog wystawy starożytności i przedmiotów sztuki I 856 urządzonéj w Patacu Jw. hr. Augustostwa Potockich w Warszawie na Krakowskiem-Przedmieściu, na korzyść Domu Schronienia Opieki Najświętszej Maryi Panny (1856), Warszawa.

Kiersnowska T. (2000), głos w dyskusji, [w:] H. Samsonowicz (red.), Ziemie polskie $w X$ wieku i ich znaczenie $w$ ksztattowaniu się nowej mapy Europy, Uniwersitas, Kraków, s. 236-238.

Kordala T.(2006), Wczesnośredniowieczne cmentarzyska szkieletowe na pótnocnym Mazowszu, Wydawnictwo Inicjał 3, Łódź (Monografie Instytutu Archeologii Uniwersytetu Łódzkiego, 5).

Kotowicz P.N. (2014), Topory wczesnośredniowieczne z ziem polskich. Katalog źródet, Mitel, Rzeszów (Collectio Archaeologica Ressoviensis, 30 ).

Kotowicz P.N. (2018), Early Medieval Axes from the Territory of Poland, Polska Akademia Umiejętności, Kraków (Moravia Magna Seria Polona, 5).

Kucypera P., Pranke P., Wadyl S. (2011), Wczesnośredniowieczne toporki miniaturowe, Wydawnictwo Adam Marszałek, Toruń.

Kula W.(2004), Miary i ludzie, Książka i Wiedza, Warszawa. 
Kurasiński T.(2014), Grotem w dót, grotem w górę. Deponowanie wtóczni w grobach wczesnośredniowiecznych na ziemiach polskich, [w:] T. Kurasiński, K. Skóra (red.), Grób w przestrzeni, przestrzeń w grobie. Przestrzenne uwarunkowania w dawnej obrzędowości pogrzebowej, Łódzkie Towarzystwo Naukowe, Łódź (Acta Archaeologica Lodziensia, 60), s. 159-190.

Liwoch R. (2013), Szkieletowy grób kamienny z Naczy na Biatorusi, „Materiały Archeologiczne", 39, s. 14I-I47.

Liwoch R. (2014a), Importy staroruskie w Polsce. Przyktady ze zbiorów dawnych Muzeum Archeologicznego w Krakowie, [w:] P.P. Toločko i in. (red.), Mista Davn'ö̈ Rusi, Kiïv, s. $415-423$.

Liwoch R. (2014b), Wczesnośredniowieczny grób kamienny z importem ruskim w Siemienicach nad Bzura (gm. Krzyżanów, pow. kutnowski, woj. tódzkie), „Naukovì studiì”, 7, s. $323-334$.

Liwoch R.(2016), noty, [w:] A. Tyniec (red.), Chrzest 966 - oblicza chrystianizacji. Katalog wystawy, Muzeum Archeologiczne, Kraków, s. 51-52, 83, 102.

Makarov N.A. (1992), Drevnerusskie amulety-toporiki, „Rossijskaâ arheologiâ”, 2, s. 4I-56.

Marecki J., Rotter L. (2009), Jak czytać wizerunki świętych. Leksykon atrybutów i symboli hagiograficznych, Universitas, Kraków.

Morawiec J. (2013), Knut Wielki. Król Anglii, Danii i Norwegii (ok. 995-1035), Avalon, Kraków.

Musianowicz K. (1952), Mazowieckie naczynia z cylindryczna szyjka na tle stowiańskiego materiatu porównawczego, „Wiadomości Archeologiczne”, 18.3-4, s.345-384.

Nadolski A. (1953), Miniaturowy toporek z grodziska w Tumie pod Łęczyca, „Przegląd Archeologiczny", 9.2-3, s. 389-391.

Nadolski A. (1954), Studia nad uzbrojeniem polskim wX, XI i XII wieku, Zakład Narodowy im. Ossolińskich, Łódź-Wrocław (Acta Archaeologica Universitatis Lodziensis, 3).

Olczak H., Krasnodębski D. (2019), Osobliwości obrzędowości funeralnej na przyktadzie cmentarzyska z grobami w obstawach kamiennych i kurhanami w Szczytach-Dzięciotowie, [w:] A. Buko (red.), Początki chrześcijaństwa na pograniczu mazowiecko-ruskim ws świetle wyników badań wybranych cmentarzysk, Wydawnictwo Instytutu Archeologii i Etnologii Polskiej Akademii Nauk, Warszawa, s. 72-77.

Panasiewicz W., Wołoszyn M. (2002), Staroruskie miniaturowe toporki z Gródka, pow. Hrubieszów, „Archeologia Polski”, 47.I-2, s. 245-286.

Paulsen P. (1939), Axt und Kreuz bei den Nordgermanen, Ahnenerbe-Stiftung-Verlag, Berlin.

Paulsen P. (1956), Axt und Kreuz in Nord-und Osteuropa, Rudolf Habelt, Bonn.

Piaskowski J. (1960), Metaloznawcze badania wyrobów żelaznych z okresu halsztackiego i lateńskiego pochodzacych z Matopolski, „Materiały Archeologiczne”, 2, s. 197-224.

Platonova N.I. (1998), Kamernye pogrebeniâ XI - načala XII vv. v Novgorodskoj zemle (analiz pogrebal'nogo obrâda), [w:] V.V.Sedov (red.), Obŝestvo, èkonomika, kul'tura i iskusstvo slavân, Moskva (Trudy vi Meždunarodnogo Kongressa slavânskoj arheologii, 4), s. 372-380. 
Platonova N.I. (2017), K voprosu ob interpretacii „bogatyh pogrebenij“ na drevnerusskih mogil'nikah 2-jpoloviny XI - načala XII v. (po materialam Udrajskogo arheologičeskogo kompleksa), [w:] N.I. Platonova (red.), Élite ou Égalité... Severnaâ Rus' i kul'turnye transformacii v Evrope VII-XII vv., Sankt-Peterburg, s. I24-I46.

Poczatki Łęczycy (20I4), R. Grygiel, T. Jurek (red.), Muzeum Archeologiczne i Etnograficzne, Łódź.

Rauhut L. (197I), Wczesnośredniowieczne cmentarzyska w obudowie kamiennej na Mazowszu i Podlasiu, „Materiały Starożytne i Wczesnośredniowieczne”, I, s. 435-656.

Rauhut L. (1975), Frühmittelalteriche Dorfgräberfelder in Mazowsze und Podlasie (Mittelund Nordpolen), „Ethnographisch-Archäologische Zeitschrift”, 16, s. 519-531, 573.

Rauhut L., Długopolska L. (1972), Wczesnośredniowieczne cmentarzysko szkieletowe w obudowie kamiennej w Eączynie Starym, pow. Przasnysz, „Wiadomości Archeologiczne", 37.3, s. 320-393.

Sikora J. (2009), Ziemie Centralnej Polski we wczesnym średniowieczu. Studium archeologiczno-osadnicze, Instytut Archeologii Uniwersytetu Łódzkiego, Łódź (Monografie Instytutu Archeologii Uniwersytetu Eódzkiego, 7).

Skalski K. (2002), Mazowieckie groby w obudowach kamiennych z rejonów Ptocka. Przyczynek do historii politycznej drugiej potowy XI wieku, [w:] T. Wasilewski (red.), Inter Orientem et Occidentem. Studia z dziejów Europy Środkowowschodniej ofiarowane Profesorowi Janowi Tyszkiewiczowi w czterdziestolecie pracy naukowej, Wydawnictwo Dig, Warszawa, s. 5I-64.

Skrzyńska K. (20I9), Wczesny etap chrystianizacji (XI-XIII w.): pomiędzy historia i archeologia, [w:] A. Buko (red.), Początki chrześcijaństwa na pograniczu mazowiecko-ruskim w świetle wyników badań wybranych cmentarzysk, Wydawnictwo Instytutu Archeologii i Etnologii Polskiej Akademii Nauk, Warszawa, s. 273-294.

Stownik geograficzny Królestwa Polskiego i innych krajów stowiańskich, t. VI (1885), B. Chlebowski, W. Walewski (red.), Nakład Filipa Sulimierskiego i Władysława Walewskiego, Warszawa.

Strzyż P. (2006), Uzbrojenie we wczesnośredniowiecznej Matopolsce, Łódzkie Towarzystwo Naukowe, Łódź (Acta Archaeologica Lodziensia, 52 ).

Średniowieczne cmentarzysko w Czarnej Wielkiej stan. I, woj. podlaskie (badania 195I-1978), t. II (2014), H. Karwowska (red.), Muzeum Podlaskie, Białystok.

Tarczyński F. (1900), Groby rzędowe kamienne w pow. Ptockim, „Światowit”, 2, s. 19-27.

Valk H. (2012), The Zhalnik Graves: Evidence of the Christianization of the Novgorod and Pskov Lands?, [w:] M. Salamon i in. (red.), Rome, Constantinople and Newly-converted Europe. Archaeological and Historical Evidence, t. I, Uźródet Europy Środkowo-Wschodniej / Frühzeit Ostmitteleuropas, t. I.I, Wydawnictwo Instytutu Archeologii i Etnologii Polskiej Akademii Nauk, Kraków-Leipzig-Rzeszów-Warszawa, s. 737-750.

Wawrzeniecki M.(1908), Poszukiwania archeologiczne w Królestwie Polskiem, „Materiały Antropologiczno-Archeologiczne i Etnograficzne”, Io, s. 46-98 + tabl. XVII-Xxx.

Wołoszyn M. (2006), Ze studiów nad obecnością ruską i skandynawską na ziemiach polskich wX-XII wieku, [w:] M. Dworaczyk i in. (red.), Świat Stowian wczesnego średniowiecza, Wydawnictwo Instytutu Archeologii i Etnologii Polskiej Akademii Nauk, Szczecin-Wrocław, s. 595-6r3. 


\section{Summary}

Among the old collection of the Archaeological Museum in Cracow, under the inventory numbers $\mathrm{MAK} / 3478,3664,4255$, there lie the furnishings from the graves in Siemienice. The miniature bronze axe belongs to the type II acc. to N.A. Makarov. It's a devotional artifact - Christian amulet associated with the cult of the Norwegian King St. Olaf (Olaf II Haraldsson, 995-1030), the import from Kievan Rus'. The iron spearheads belong to the types IV and v acc. to A. Nadolski, while the battle axe belongs to the type vc acc. to A. Nadolski. The iron handle and fragments of iron hoop was a part of small wooden bucket. The miniature clay pot belongs to a group of vessels with a cylindrical neck typical for Mazovia. The features from Siemienice represented so-called stone graves - a skeleton burials covered with cobbles, which make up stone cemeteries. It can be surmised that the set dates back to the second half of the $\mathrm{II}^{\text {th }}$ century or to the beginning of the $\mathrm{I}^{\text {th }}$ century. It's an examples of the grave of the end-stage phase of the druzhina culture. The sparse and, unfortunately, only partially preserved furnishings from the burials in the stone graves in Siemienice, which are presented here, supplement the knowledge concerning archaeological materials obtained from Polish stone cemeteries in the $19^{\text {th }}$ century and at the beginning of the $20^{\text {th }}$ century.

Keywords: Poland, Middle Ages, druzhina culture, stone graves, weapon, miniature axe

\section{Radosław Liwoch}

Muzeum Archeologiczne w Krakowie

e-mail: radliw@interia.pl

(c) by the author, licensee University of Lodz - Lodz University Press, Łódź, Poland. This article is an open access article distributed under the terms and conditions of the Creative Commons Attribution license CC-BY-NC-ND 4.0 (https://creativecommons.org/licenses/by-nc-nd/4.0/) 